\title{
ECONOMICS
}

\section{THE INTERNATIONAL EFFECTS OF CHINA'S GROWTH, TRADE AND EDUCATION BOOMS}

by

Richard G. Harris Simon Fraser University

and

Peter E. Robertson

Business School

The University of Western Australia and

Jessica Y. Xu

The University of New South Wales

DISCUSSION PAPER 10.04 
THE INTERNATIONAL EFFECTS OF CHINA`S GROWTH, TRADE

\title{
AND EDUCATION BOOMS
}

\author{
Richard G. Harris \\ Simon Fraser University \\ and \\ Peter E. Robertson ${ }^{*}$ \\ Business School \\ The University of Western Australia \\ and \\ Jessica Y. Xu \\ The University of New South Wales
}

January 2010

China's international trade flows have increased by $500 \%$ since 1992, far outstripping GDP growth. Likewise tertiary education enrollments have increased by $300 \%$. We simulate these changes using a multi-sector growth model of the Chinese and USA economies. A decade of trade biased growth in China is found to have a large effect on the USA economy - raising GDP approximately 3-4.5 percentage points. We also show that the trade bias in China's growth accounts for more than half of the observed growth in tertiary enrolments in China. In contrast neutral growth has practically no effect on USA incomes or China's stock of skilled labour. Finally the simulations reveal that China's education boom per se has practically no long run impact on the USA economy. The results thus indicate that the pattern of productivity growth in exports sectors, as might be caused by falling trade costs, has been critical in transmitting benefits of Chinese growth to the world economy. They also point to an important link between falling trade costs and human capital formation.

\section{Keywords: Economic Growth, China, Human Capital, Trade Costs.}

JEL: O4, O1, F11, F43

\footnotetext{
* Corresponding Author; Peter E. Robertson, Economics, School of Business, University of

Western Australia, Perth. Email: peter.robertson@uwa.edu.au
} 


\section{Introduction}

What is the impact of China's growth on the world economy? In thinking about answers to this question two facts stand out. First, China's growth has been extremely biased. In particular, China's international trade flows have increased by $500 \%$ since 1992, far outstripping GDP growth, and have changed dramatically in their composition (Amiti and Freund 2008). This is noteworthy since standard trade theory indicates the importance of biased growth as source of terms-of-trade gains to other countries. ${ }^{1}$ Second as documented by $\mathrm{Li}$ et al. (2008), over the last decade China's investment in human capital has undergone a massive boom. The fraction of the labour force with tertiary degrees has doubled since 1992 and tertiary enrolments have increased by 300\% over a similar period. Thus along with China's trade shares, China's endowment structure is also changing rapidly and potentially this may also affect have consequences for the intrenational economy.

Aside from trade and wage inequality literature, however, little is known about the effects of Chinese growth on other countries. For example, we know very little about how China's growth affected factor accumulation and economic growth in other countries, or about how its chnaging trade pattrens and endowmnets hare affecting its trading partners? ${ }^{2}$ Likewise little is known about how these aspects of China's growth are related. In particular, how is China's growth and export boom related to its education boom? Can the education boom explain the changes in

\footnotetext{
${ }^{1}$ For example in the Heckscher-Ohlin trade model, growth in one country will have no impact on the rest of the world, irrespective of how large the country is or how fast the growth rate is, unless it is biased towards one sector.

${ }^{2}$ An extensive literature on this subject exist focusing in particular wage inequality, the growth and sophistication of China's exports, and, more recently, the effects of China's education boom on the world supply of skilled workers, Freeman (2007) and Li et al. (2008). For example see: Krugman (2008) and Lawrence (2008) on wage inequality; Rodrik, (2006) and Branstetter and Lardy (2006) on the changing technological sophistication of China's exports, and the implications for "hightech" manufactured export sectors. Likewise, recent media debates on China's de-coupling from USA, such as The Economist (2006, 2008) relate to the effects of China's expansion on USA economic growth. In addition several papers have recently begun to explore the effects of China's trade flows on other countries trade patterns. For example see Athukorala (2009).
} 
trade, or can falling trade costs and changing pattern of trade account for the education boom. The aim of this paper therefore is undertake a quantitative assessment of the broad stylized facts regarding China's growth, trade bias and education boom, focusing in particular on their impacts on the USA.

To do this we construct a model of the Chinese and USA economies. The model incorporates both optimizing physical and human capital accumulation decisions and multiple traded and non-traded sectors. The model is then solved with endogenous productivity parameters, to reproduce the stylized facts of China's growth and trade bias. The simulations show, first, that trade biased productivity growth, or falling trade costs, accounts for: 50-70\% of China's overall productivity growth. That is $50-70 \%$ of China's overall productivity originates in export sectors. Second they show more than half of the observed increase in tertiary enrolments, is explained by the sector biased productivity growth. Third they show that China's trade bias has a large impact on the USA: raising GDP per capita by $3.5-4 \%$ over a decade. Conversely, however, the results also show that China's education boom, and its implied long-run 85 percent expansion in skilled labour stocks, has practically no effect on the USA. Likewise counterfactual simulations show that if China's growth was neutral, there would practically no impact on the USA.

The remainder paper is organized as follows. Section 2 describes the model structure. Section 3 establishes some stylized facts regarding China's growth patterns and presents a brief review on China's growth and trade history over the last decade. Section 4 provides an overview of China's higher education situation and reforms to expand its enrolments in higher education level. Section 5 discusses the experiment design and the results are reported in Section 6 and 7. Section 8 concludes by summarizing the main findings.

\section{Methodology}

Calibrated neo-classical growth models have been widely used to look at long run development issues. Examples include Parente, Rogerson and Wright (2000), Hansen and Prescott (2002), Graham and Temple (2006), and Hayashi and Prescott (2008). In this literature, however, the models are constrained to one or 
two sectors and to closed economy settings. This necessarily restricts the role of trade and any potential trade and growth interactions, which is a significant limitation in attempting to understand China's growth.

To allow for trade-growth interactions we introduce long run neoclassical steady state factor accumulation conditions into an open economy C.G.E model. The model includes eleven sectors (6 traded and 5 non-traded) and three separate regions (China, USA and Rest of World). The focus of the model is to see how commodity price changes can affect factor prices - the Stolper-Sameulson effects and how these in turn affect capital and human capital accumulation decisions in each country. Both regions are modeled as small open economies with respect to the Rest of the World (ROW), but not with respect to each other. Thus growth in China, for example, will have an impact on prices in the USA. The appendix also briefly describes the model used in this paper in a non technical fashion, focusing on the features of the model that most assist in understanding the results. ${ }^{3}$

The model is employed in the following way. We begin by specifying some important stylized facts regarding China's growth. We then then solve the model with endogenously chosen technology parameters so that these stylized facts are reproduced exactly by the model solution. Thus we first ask, what must be assumed about neutral technical change; trade sector biased technical change, and government funding of education education - to reproduce different aspects of China's growth experience?

Having reproduced the growth pattern, the model simulations then tell us what the impact of this biased pattern of growth has been on the main endogenous variables of interest, particularly wages, sectoral outputs and income levels in the USA, and also education enrollments and human capital accumulation in China. We can obtain a quantitative measure of the effects of trade bias for example, by considering both sector neutral productivity growth that reproduces China's GDP growth, with a combination of neutral and trade-sector specific productivity growth that reproduces not only China's GDP growth, but also the pattern of export growth. As discussed below, the results from these comparisons of

\footnotetext{
${ }^{3}$ A full technical description of the model is available from the authors.
} 
alternative simulations, point to the enormous impact of trade biased growth falling trade costs - for the the USA and also for raising education levels in China.

\section{Growth in China - Some Stylized facts}

As noted above, China has not only grown very rapidly, but the traded good sector has far outstripped growth in the rest of the economy. Moreover, the endowment structure has changed, as has the composition of trade. In this section, we briefly review the data and describe some broad stylized facts regarding the average rate of growth, the changes in trade shares of GDP and the changes in China's export composition. Specifically over this period we show that China has experienced: a growth rate of GDP per capita of 8.9 percent per year; a 59 percent increase in exports to GDP ratio; and an 85 percent increase in higher education investments, as measured by enrollments. In addition we also consider changes in commodity export shares and tariff reductions over the last decade.

\subsection{Post Cultural Revolution Growth Rate}

The measurement of China's economic growth has not been without controversy. Ruoen (1995) and Woo (1998) argue that the official GDP deflators are biased and tend to understate inflation. Using an alternative price deflator series and adjusting alternative labour market participation data, Young (2003) finds that China's growth rate over the reform period 1978-98 is reduced significantly from official figures. ${ }^{4}$

However, the alternative data for the latest decade of China's growth, 1995-2005, appear to be more consistent. Table 1, taken from unpublished data used in Bosworth and Collins (2008), compares different estimates of average growth rates in China. As shown in Column 2, the official growth rate of $8.05 \%$ per year falls to $6.71 \%$ per year using the price deflator series preferred by Young (2003). ${ }^{5}$ Bosworth and Collins' (2008) preferred estimates are given in Column 3 which uses the alternative price deflators for the industrial sector but the official deflators for agriculture and services. It can be seen that the differences in these

\footnotetext{
${ }^{4}$ Young (2003) finds that the official growth rate of GDP per capita of $7.8 \%$ per year is reduced to an estimate of GDP per worker of $5.2 \%$ per year.

5 This uses the official index of employment and not Young's (2003) alternative series.
} 
series have declined in recent years. In what follows, we shall assume a growth rate of GDP per worker of $8.9 \%$ per year over the decade 1995-2005, based on Bosworth and Collins' (2008) preferred estimate.

[Table 1 about here]

\subsection{China's Trade Shares}

A second set of stylized facts concern China's trade flows. First, the value of trade has been growing more rapidly than GDP - leading to a rising trade share of GDP. Figure 1 illustrates this by showing total Chinese export and import values as a fraction of GDP. It can be seen that the trade share of GDP has approximately doubled since the 1990's.

[Figure 1 about here]

Second, the composition of China's trade has also changed dramatically in the last decade. As emphasized by Schott (2006) and Rodrik (2006), and Amiti and Freund (2008), China's export bundle has become increasingly sophisticated. Table 2 shows the value shares of China's exports in 1990, 1995 and 2005. It shows that there has been a very dramatic decline in agricultural goods over the last 15 years and a more than doubling of the share of durable in China's export basket.

[Table 2 about here]

The measurement of trade shares, however, is also the subject of some debate. Anderson (2007) has argued that the recent acceleration in the exports relative to GDP in this decade largely reflects measurement error. ${ }^{6}$ Nevertheless, Anderson (2007) also reports larger increases in export to GDP ratios over slightly longer periods, such as 1990 to 2005.

\footnotetext{
${ }^{6}$ Anderson (2007) finds that there has been a rapid growth in gross output relative to value added in manufactured goods. Hence trade flow values - which are gross output measures - have also risen relative to value added. Anderson (2007) attributes the growth in gross flows relative to value added flows to measurement error.
} 
There are several other non-mutually exclusive explanations for the rise in trade to GDP ratio and changes in export composition. Part of this expansion for both the changing level and pattern of trade is likely to be due to falling trade barriers. Rumbaugh and Blancher (2004) report that the average (unweighted) tariff rates in China fell from $55.6 \%$ in 1982 to $12.3 \%$ by 2002 . The most rapid change was during the 1990's. Table 3 reports data derived from the World Bank's Trade, Production and Protection database, specifically for the period of interest, 19952004. ${ }^{7}$ It shows that China's tariffs, on both the USA and ROW, fell substantially over this period. ${ }^{8}$

\section{[Table 3 about here]}

A second consideration is productivity growth. Some studies have claimed to find evidence that productivity growth has been higher in export sectors. ${ }^{9}$ A related explanation is that export specific productivity growth has occurred due to falling trade costs and this rise of global fragmentation of production (Jones and Kierzkowski 1990, Deardorff 2001, Yi 2003). This geographical fragmentation of production is best understood as a result of changes in technology and falling trade costs. Specifically, fragmentation is only possible if trade and communications costs are sufficiently low.

Unfortunately, as noted by Anderson and van Wincoop (2004) and Hummels (2007), the evidence on how trade costs have fallen over time and the relationship to global fragmentation is very limited. ${ }^{10}$ Athukorala (2003), Branstetter and

\footnotetext{
7 The data base reports nominal tariff rates from 1976-2004 at ISIC Rev. 2 level. Table 3 reports aggregated data which corresponds to the sectoral aggregation used in our numerical model.

${ }^{8}$ It is possible that these nominal tariff rates overstate the amount of protection in earlier years since they do not incorporate duty exemptions for export processing sectors that may have been in place before 1995. On the other hand, these rates also exclude non-tariff barriers which, according to some studies, imply tariff equivalents at least as high as nominal tariff rates, (Zhang 2001, Bach et al. 1996) .

${ }^{9}$ Perkins (1997) and Amighini (2005) also provide evidence of the rising productivity of China's traded goods sector.

${ }^{10}$ For further discussion, see Hummels (2007) and Baldwin and Robert-Nicoud (2006). In particular, gravity equations have revealed mixed evidence on whether trade costs have fallen over
} 
Lardy (2006) nevertheless argue that this fragmentation been particularly pronounced in the East Asian region with the integration of China into production networks. Amiti and Freund (2008) also provide evidence to suggest that fragmentation lies behind the apparent increasing skill intensity of China's exports.

Another source of biased productivity may relate to foreign investment patterns. According to Branstetter and Lardy (2006) and Lardy (2003), the sectors that have expanded, such as transport, machinery and electronics, are those where foreign investment has been largest. During the 1990's, the government reduced the nontariff barriers and also introduced special privileges for export processing firms including all foreign owned and joint owned firms.

Thus, in modeling China's trade biased growth, we want to allow both for falling trade barriers, changes in trade costs and other sources of trade biased productivity growth. In what follows, we therefore introduce trade biased technological change in a parsimonious way that can be interpreted either as falling trade costs, or direct productivity gains specific to traded good sectors.

\section{Tertiary Education Reforms}

The rapid expansion of skilled labour in China has occurred on the back of a long reform process in education and rapid growth. It is also a result of deliberate government targets which have been set in response to a perceived skills shortage. These supply side changes, however, may be seen also as a policy response to rising demand for higher education as a result of China's growth.

In order to disentangle the effect of education policy changes from endogenous factors, we first consider the quantitative impact of China's trade biased growth, as discussed above, on the supply of skilled labour. We then examine the impact education subsidies required to meet the observed education enrolment increase, and examine the long run implications of these education policy changes.

time. However, Bussière and Schnatz (2009) suggest that China's trade pattern does not appear to be extraordinary, given expected trade patterns they estimate using a gravity model. 


\subsection{Growth in Tertiary Enrolments.}

Freeman (2007) and Li et al. (2008) have recently drawn attention to possible international economic implications of the education revolution that is occurring in China. As shown in Figure 2, the ratio of tertiary student enrolments to the labour force in China has approximately doubled in just four years. It increased from a rate of $1.2 \%$ in 2000 to $2.2 \%$ in 2004 , which is an $85 \%$ increase. In absolute numbers, this represents an increase of 8.3 million tertiary students. ${ }^{11}$ Figure 2 also reports data from Islam et al. (2006) suggesting the skill intensity of China's workforce has been growing consistently since the end of the Cultural Revolution.

[Figure 2 about here]

This poses two questions. First, what is the cause of the rise in enrolment rates? In this section we briefly outline a number of reforms that have allowed an increase in education supply. In addition to these reforms in the education sector, we also wish to explore the role of China's growth, and in particular the trade bias of the growth, in understanding the increase in education investment.

Second, what is impact of this expansion in enrolments on China's endowment of skilled labour and trade patterns? As noted by Freeman (2007) and Li et al. (2008), China's sheer size means that a rising skilled labour force may have a significant effect on the world supply of skilled labour, and hence also on international trade patterns. What is the long term impact of the increased tertiary education investment? In a new steady state the $85 \%$ increase in education enrollments investment will also raise skilled labour stocks by $85 \%$, because the ratio of students to labour force must be constant. Thus in the long run the education boom will have an equally large impact on China's skilled labour endowment. In the final part of this paper, we use our model to examine this long run effect on China's GDP trade and also on the USA economy.

\footnotetext{
11 The enrolments refer to students in regular higher education institutions and adult higher education institutions. Despite this growth, China's tertiary gross enrolment rate, which was 19.1 percent in 2004, was below the world average of 24.8 percent. This suggests that, in relative terms, the education plan is an accelerated programme of catch-up to "normal" levels.
} 


\subsection{Education Reforms and Planning}

Initially, China's reform process amounted to an undoing of the impact of the Cultural Revolution. Tsang (2001) and Chow (2002), among others, document how as part of this policy, higher education in China ceased from 1966 to 1976. Though enrolments recovered at the end of the Cultural Revolution, the current education boom did not begin until the late 1990's.

The recent expansion in enrolments exceeded the targets set out in the "Tenth Five-Year Plan”, covering the period 2001 to $2005 .^{12}$ The targets were achieved through several different policies. First, is the rise in private education institutions. Private institutions of higher education - known as "minban" institutions - were legally established in the 1990s. By 2004, there were 226 minban institutions with 1.4 million students (Zhang, 2006; Min, 2005). Likewise, until 1990, universities did not charge students for tuition, but by 2004 , fees accounted for $18.6 \%$ of educational expenditures (Zhang 2006, Min 2005 and Hannum et al. 2008).

Second, the government has increased funding for secondary and tertiary education. China's aggregate education expenditure as a percentage of GDP grew from $3.4 \%$ in 1991 to $5.3 \%$ in 2004 . Though the proportion of funds for education coming from government has fallen from $85 \%$ percent in 1991 to $62 \%$ in 2004, public funding has still grown as a share of GDP (Hannum et al. 2008). The "Eleventh Five-Year Plan" aims to increase public spending relative to GDP to $4 \%$ - which is a $66 \%$ increase over the level in the mid $1990 \mathrm{~s}$.

Reforms in the labour market have also complemented the liberalisation policy in higher education. Historically, the wage policy in China forced a low rate of return to skilled labour and there are still distortions on the wage setting in the labour markets (Knight and Shi 1996, Young 2003, Heckman 2005 and Fogel 2006). Fleisher and Wang $(2004,2005)$ and Fleisher et al. (2006) suggest that these wage differences understate the return to education by 30 to $40 \%$. Heckman and $\mathrm{Li}$ (2004), however, report evidence that the return to education has been rising in response to labour market reforms.

\footnotetext{
12 The Chinese government set a target of 16 million students to be enrolled in tertiary institutions. That goal was surpassed in 2004 with 18.9 million students.
} 
Thus, the combination of: reforms to education sector; increased government spending, and; reforms to the labour market have provided the basis for the expansion in enrolments. In addition, however, given the rapid growth and growth of manufacturing output, China was also likely to have experienced rapid growth in demand for skilled labour. Indeed, according to Tsang (2001), the motive for the supply side measures - such as raising education enrolment targets - was that China was perceived to be facing a "skills shortage" which was thought to be a bottleneck to sustaining current growth rates.

\section{Policy Simulations}

Our aim is to provide some quantitative insights into: (i) how China's economic growth, and growth bias, has affected the long run stock of skilled labour, (ii) how this growth bias has affected the USA economy, and (iii) how the expansion of China's stock of skilled labour, including the long run effects of recent education reforms reforms, might have affected China and USA economies.

We begin by constructing a benchmark equilibrium. This is calibrated to steady state growth path where all variables are growing proportionally, prices and factor returns and the debt to GDP ratio are constant, and there is balanced trade.

Bosworth and Collins' (2008) measure of growth of $8.9 \%$ implies a 2.15 fold increase in GDP per capita over a decade. The underlying assumed world trend rate of growth, of just under $2 \%$ per year, leaves an additional growth premium for China of $6.8 \%$ per year, or equivalently, a $80 \%$ increase in GDP per capita, above the trend rate over 10 years. ${ }^{13}$

In the simulations below, we use this figure as a target for the aggregate growth of the Chinese economy. We shall consider alternative combinations of sectoral

\footnotetext{
${ }^{13}$ We assume a long run trend growth rate for China, the USA and the ROW of $(1+n)(1+\gamma)=$ 1.03 and a long run population growth rate of $1+n=1.01$, which gives an implied long run growth rate productivity growth rate of $\gamma=1.98 \%$. Given an assumed annual growth rate in China over this decade of $8.9 \%$ then we have $(1+0.0892) /(1+0.0198)=1.068$, so that $6.8 \%$ is the required additional growth rate above trend. Finally, for $T=10$ years we have $1.068(T-1)$ $=1.80$.
} 
productivity parameters which, in combination with endogenous accumulation responses, generate an $80 \%$ fold increase in GDP per capita. Thus, the total amount of growth is fixed across each simulations. Across different simulations however, the composition of growth and sectoral bias of this growth will vary.

Second, as shown in Figure 1, from 1995-2005 the export to GDP ratio has increased from approximately 23 to $37 \%$ while the import to GDP ratio increased from 21 to $32 \%$. We use export and import to GDP ratios based on the average of these values as a target value. Thus, exports and import growth is targeted to grow from $22 \%$ of GDP in the base to $35 \%$ of GDP - that is, a target increase of $59 \%$.

As discussed, we employ combinations of changing trade cost parameters and falling tariff rates that achieve the export growth targets observed in the data. Firms in the model face a revenue function that describes the revenue faced by selling to each market. The parameters of this revenue function can be interpreted as trade costs (Bergstrand, 1985, Baier and Bergstrand, 2001). That is, they represent the fraction of value received by firms per unit of value received in each market. We denote these revenue function, or trade costs parameters, for China's exports of each traded good $i$, as $\lambda_{i, U S A}$, and $\lambda_{i, R O W}$. In the benchmark we normalize these to unity. A value greater than unity therefore means that trade costs have fallen relative to the benchmark. Specifically, a fall in trade costs associated with China's export markets means that $\lambda_{i, U S A}>1$ and $\lambda_{i, R O W}>1$.

Given these productivity parameters, we proceed as follows. Simulation 1 ( $s 1$ ) examines the effect of a pure labour augmenting increase in productivity: that is a uniform increase in the effective labour supply parameters on skilled and unskilled labour, $A_{L S, i}, A_{L U, i}$ across all sectors, $i=1-11$.

In the second simulation, $s 2$, we add to this a uniform fall in Chinese export trade costs across all tradable sectors. Thus, we choose $\lambda_{i, U S A}=\lambda_{i, R O W}=\bar{\lambda}, \forall i$, such that the export to GDP ratio adjusts to a target increase of $59 \%$.

In $s 3$, we allow for productivity bias across the traded goods sectors. Thus, we choose $\lambda_{i, U S A} \neq \lambda_{i, R O W}, \forall i$ so that (i) the export value share in each sector reaches 
their 2005 share value, as given in Table 2, and (ii) the export to GDP ratio increases to its $59 \%$ target as before. Thus, in $s 3$ we allow for composition of trade effects. In $s 4$, the targets remain the same but we also include the tariff reductions described in Table 3 . The simulations, with relevant targets and assumed endogenous variables are summarized in Table 4.

[Table 4 about here]

\section{Results: Trade Biased Growth}

\subsection{Steady-State Solutions for China}

Table 5 records the steady state solutions to the simulations, $s 1-s 4$, for China and the results for the USA are reported in Table 6. From Table 5, column $s 1$, it can be seen that the target increase in GDP requires a $107 \%$ increase in the labour productivity parameters, $A_{S}$ and $A_{U}$. It can be seen further that the exogenous productivity growth also generates an $85-96 \%$ increase in the physical capital stocks.

[Table 5 about here]

It can also be seen, however, that the assumption of labour augmenting productivity change generates a number of counterfactual results. In particular, exports as a fraction of GDP do not increase, but fall by $26 \%$. Intuitively, this is because the Chinese domestic economy, including the non-traded goods sector, has grown relative to the world economy. Thus the multi-product firms substitute away from export markets and towards the domestic market.

Likewise, under neutral productivity growth, the pattern of growth across sectors is also very even. With respect to skilled labour, neutral growth does induce accumulation of skilled labour but the increase of $18 \%$ is again small relative to the stylized facts where tertiary education enrolments have approximately doubled. Thus, the assumption of labour augmenting productivity does not explain the strong labour up-skilling or rising trade-GDP ratios that have been features of Chinese economic growth. 
Columns $s 2$ and $s 3$ of Table 5 shows the effects of falling trade costs, or equivalently, trade-sector biased growth. In $s 2$, this is achieved by endogenously choosing the trade cost parameters for China's exports to the USA and to the $R O W, \lambda_{i, U S A}$ and $\lambda_{i, R O W}$, where the change in these parameters is constrained to be the same across the regions and commodities, $\left(\lambda_{i, U S A}=\lambda_{i, R O W}=\bar{\lambda}, \forall i\right)$. These adjust in such a way that the export to GDP ratio increases by the target of $59.1 \%$.

It can be seen in Table 5, column $s 2$, that this trade-GDP target requires a $93 \%$ increase in $\lambda_{i, U S A}$ and $\lambda_{i, R O W}$ across all traded goods sectors, (or equivalently, a $52 \%$ fall in trade costs). The presence of trade-biased growth also reduces the required aggregate labour augmenting productivity substantially, from $107 \%$ to just $38 \%$. Thus falls in trade costs consistent with observed export shares, is capable of accounting for the bulk of China's productivity growth.

Allowing for trade biased productivity growth also generates dramatic impact on the stock of students and skilled labour, which increase by $46 \%$. Thus trade biased productivity growth also accounts for a large fraction of the observed 85\% increase in enrolments. This suggests that there is an important link between falling trade costs and skill accumulation. This, moreover, is a topic which has received very little attention in either the trade or growth literature. ${ }^{14}$

Another important effect of allowing for trade biased technical change (or falling trade costs) is on the terms of trade. With neutral growth there is a $10.7 \%$ fall in the terms of trade, but with trade biased growth this increases to a $39 \%$ fall. We shall return to this in our discussion of the implications for the USA, below.

Allowing for trade biased growth in $s 2$, nevertheless, results in counterfactual outcomes for the export shares. The share of low-tech manufacturing in $s 2$ is more than double the actual value in China in 2005 and the share of Durables is only half the actual value. Thus, in $s 3$ we introduce sector specific export share targets, using the changes in sectoral export shares between 1995 and 2005 in Table 2. To meet these targets we allow the trade cost parameters, $\lambda_{i, U S A}$ and $\lambda_{i, R O W}$ to vary across sectors.

\footnotetext{
${ }^{14}$ See for example, Pavcnik (2003), for a recent exception.
} 
The results of this experiment are reported in column $s 3$ of Table 5. The most notable difference between $s 2$ and $s 3$ is that $s 3$ involves larger trade costs reductions in Durables exports, relative to the other sectors. This results in even greater skilled labour accumulation - with a 53\% increase in the stock. Thus, both the increased trade volume, as well as the changing trade shares, have contributed to rising demand for skilled labour.

Next, we allow for the changes in tariffs that occurred 1995-2005, as reported in Table 3. As shown in column $s 4$ of Table 6 , allowing for the changes in tariffs again results in only small changes relative to $s 3$. The required fall in trade costs is reduced substantially relative to $s 3$, due to the effects of the tariff, but there is still a very large, $49 \%$, increase in skilled labour stocks and the terms of trade effects are similar. Thus, from the experiments $s 1$ to $s 4$ we conclude that China's trade sector biased economic growth is a more plausible explanation than Harrod neutral non-sector specific productivity growth. It also accounts for a substantial increase in tertiary enrolments, and hence the long run skilled labour stock, and also generates substantial falls in China's terms of trade.

\subsection{Impacts of Chinese Growth for the USA}

The impact of these simulation experiments on the USA is shown in Table 6 . First, we note that under the assumption of neutral productivity growth, $s 1$, there is practically no impact on factor incomes in the USA. This, of course, is related to modest terms-of-trade effects in this experiment.

\section{[Table 6 about here]}

Allowing for the rise in China's trade-GDP ratio in s2, however, generates a $8.6 \%$ improvement in the USA terms-of-trade and a $33 \%$ increase in its export to GDP ratio. ${ }^{15}$ These flow through to significant aggregate benefits with a $3.8 \%$ increase in USA's GDP and a similar 3.5\% increase in consumption. It can be seen further that the increase in GDP is generated by capital deepening and a significant fall in

\footnotetext{
${ }^{15}$ Since trade is balanced in equilibrium this also implies an identical increase to import-GDP ratio for the USA.
} 
the price of traded goods. Thus the gains in the USA are driven primarily by the lower cost of capital generating increased capital deepening.

Including sector specific trade cost reductions, $s 3$ further increases the change in USA GDP to $4.5 \%$. The main impact of this change, however, is on the distribution of USA output levels. The greater reduction in trade costs for Chinese Durables exports in s3 implies a $43 \%$ decline in USA Durables output. Finally, allowing for Chinese tariff reductions in $s 4$ moderates these changes somewhat, though the results are broadly similar to those in $s 3$. Thus, results suggest that Chinese growth has had quite a large impact on USA income levels and has also caused a large contraction in Durables output. ${ }^{16}$

Finally, the effects of China's biased growth on the USA labour market has received considerable attention in the literature but less attention has been given to the long run effects on skill accumulation in the USA. Furthermore, though early studies have found limited evidence that trade affects wage inequality, Krugman (2008) claims that the impact of China's economic expansion on international trade patterns over the last decade, which is our focus, is likely to be much greater than was observed previously, due to its dramatic increase in size and much greater prominence of the tradable goods sector.

In Table $6 s 3$ we see that Chinese growth increases both skilled and unskilled wages in the USA by approximately $3 \%$. Likewise, in cases $s 2$ and $s 4$, there is strong growth in both skilled and unskilled wages in the USA with little long run change in the skill premium. It can also be seen, however, that China's growth leads to a $0.7-1.7 \%$ increase in the USA stock of skilled labour across these experiments. Thus the impact on the labour market in the long run are relatively neutral for wage inequality, but nevertheless imply significant wage growth and skill deepening in the USA.

\footnotetext{
${ }^{16}$ More detailed results, not reported here, show that the USA's exports to the $R O W$ decline, but exports of Durables to China experience a dramatic increase - for example by $79 \%$ in scenario $s 4$. Thus China's expansion crowds out the USA's exports to the $R O W$ but creates new market opportunities in China as well.
} 


\section{Long Run Implications of China's Education Boom}

\subsection{Education reforms}

Simulations $s 1-s 4$ not only draw out the implications for China's growth on the USA, but also illustrate the effects of biased growth on skill upgrading in China. Importantly, falling trade costs were shown to have a large effect on the equilibrium quantity of skilled labour.

As discussed above, there have also been reforms in the education sector and increases in government spending. To capture the impact of these policy environment influences factors on China's skill-upgrading, we consider the impact of an increase in tertiary education subsidies. The subsidies capture the effect of increases in government spending on education. Moreover, to the extent that some of the reforms can be thought of as removing quotas on education enrolments, the increase in subsidies can also be thought of as an index of these reforms, given the tariff-quota equivalence.

Specifically, we set an education target equal to the $85 \%$ expansion of education enrolments. Then, in $s 5$, we choose an education subsidy, $s$, such that the stock of tertiary students increases to the target value. The value of the education subsidy is assumed to be zero in the base, and the new level is thus endogenously determined.

Next, in order to allow for the expansion in education demand due to trade biased growth, we add in all the trade and labour augmenting productivity and tariff rate changes that were derived in $s 4$ above. These are added as exogenous changes in the model. To this we then add the $85 \%$ education enrollment target and allow the education subsidy to adjust endogenously and compute the percentage differences from $s 4$. We label this experiment as $s 6$. The results in $s 6$ thus report only the incremental effect of the government's education supply changes, conditional upon China's trade biased growth experience. ${ }^{17}$

\footnotetext{
${ }^{17}$ An alternative way to think about the education enrolment rise is that it is due to labour market reforms which allowed the skilled labour wages to become closer to their marginal product. Thus, an alternative strategy would be to choose a reduction in income taxes on skilled labour such that
} 


\subsection{Results}

The results, in $s 5$ of Table 7, show that meeting the education target without the benefit of trade biased economic growth, requires an education subsidy of approximately 91.8 cents per dollar - from an assumed base subsidy of zero. The education subsidy has a relatively large impact on GDP in China, of $6.8 \%$, but a much less dramatic increase in consumption. Somewhat counter-factually, however, it also results in a $51 \%$ fall in skilled wages and exports relative to GDP.

[Table 7 about here]

The more sophisticated experiment is $s 6$ where we first reproduce the results for $s 4$ by incorporating all the endogenously determined trade costs and labour productivity changes - as well as the tariff changes - as exogenous changes, and then also add the endogenous education subsidy and education target. We know from the preceding discussion that the biased productivity growth generates an endogenous education expansion of $49 \%$. Column s6 reports the incremental effect of these education subsidies compared to $s 4$. It can be seen that the education required to meet the observed targets is now only 51.9 cents per dollar.

Naturally, the education subsidy causes a rise in skilled labour but otherwise the incremental effects are quite modest. GDP rises only $2 \%$ relative to the trade biased growth benchmark, $s 4$, but consumption only increases by $0.6 \%$ due to the greater fraction of GDP spent on investment. Skilled wages are shown to fall by $22 \%$, but this is relative to a base case, $s 4$, in which wages rising by $28 \%$. Thus the combination of education subsidies and trade biased growth leave skilled wages relatively unchanged. Likewise, education subsidies exert only a small negative effect on trade levels of half a percent.

\section{[Table 8 about here]}

Finally, Table 8 shows that the impact of China's education policy on the USA is minimal - the largest changes being a $0.5 \%$ increase in exports and minerals

the education target is reached. It turns out, however, that with the government fiscal rule there is an equivalence result between skilled labour income taxes and education subsidies. Both policy tools, when used to attain the education enrolments target, give identical results. 
production. These modest results stand in contrast to the attention given to China's rapid education expansion in recent literature. In our conventional trade and growth settings, the effects of this expansion, even in the long run, is likely to be very small. This insignificance is highlighted when compared to the effects of trade biased growth in China on the USA economy, which were large and positive. Moreover, the education itself is perhaps best seen as largely a consequence of the growth.

\section{Conclusion}

Our simulation results indicate that the last 10 years of Chinese economic growth is responsible for $3-4.5$ percentage points of growth in the USA above its trend rate. In contrast, we have found that a potential $85 \%$ increase in China's skilled labour supply, which is an implied as well as a long run consequence of its tertiary education boom, has effectively no impact on the USA economy. This suggests that either anxiety or effusiveness over the effects of this change on the USA, may well be misplaced, especially relative to the effects of China's growth.

Second, we have found that the bias of productivity growth is crucial in understanding the international transmission effects of growth. Specifically an $80 \%$ increase in Chinese GDP generated by labour augmenting productivity has practically no effect on USA consumption or GDP. The extent of gains to the USA from Chinese economic growth thus depend critically on the sources of the growth, with trade biased growth - such as falling trade costs - generating greater terms of trade gains for the USA. This points to the importance of understanding trade frictions and the sources of increased trade flows for world economic $\mathrm{g}$.

Finally, we have also shown trade biased growth generates a large increase in education demand and skilled labour supply in China. Thus, despite the fact that there have been many supply side policy reforms in China's tertiary education system, the model indicates that the trade biased productivity growth in China can account for more than half of the observed growth in tertiary enrolments in China over the last decade. To the extent that falling trade costs are a feature of the modern era of globalization, our results suggest that this may be having a large 
impact on skill formation in China, and potentially other developing economies where there has been export led growth. 


\section{Appendix}

\section{A.1 Trade and Goods Production}

The model consists of three regions. Let $\bar{R}$ denote the set of regions, $\bar{R}=\{1,2,3\}$ where $1=\mathrm{USA}, 2=$ China and region 3 is the rest of the world $(R O W)$. It will also be convenient to define a subset of non-ROW regions, $R=\{1,2\}$. In each region we consider the decisions of three agents, households, a government and firms. We begin, in this Section, by describing firms production and factor input decisions.

Trade arises from the assumption that firms are joint producers producing three goods, each distinguished by its market destination. Thus firms' in each region make regional supply decisions to maximize revenue and factor input decisions to minimize costs. Revenue maximizing behavior gives rise to the unit revenue function, which we assume to have a Constant Elasticity of Transformation form. The prices in each region reflect trade barriers, differences in technology of the cost functions facing firms, differences in the expenditure functions of the agents, and differences in endowments. Specifically an increase in $\lambda_{i, j}^{r}$ has implies a fall in the costs of region $r$ 's exports to region $j$ for commodity $i{ }^{18}$

Following the standard small-open-economy assumption, the USA and China face a constant world price for goods exported to the $R O W, p_{i}^{r, 3}$. The non-ROW regions, however, are not small with respect to each other and their export supply decisions will affect their prices. Thus the model captures the first order terms-oftrade effects of Chinese growth on the terms of trade in China and the USA. This

\footnotetext{
${ }^{18}$ The unit export supply functions of good $i$ from region $r \in R$ to region $j \in \bar{R}$ are then given by the envelope theorem as $\partial \phi_{i}^{r} / \partial p_{i}^{r j}$, for $r \neq j$. Unit domestic supplies are likewise given by $\partial \phi_{i}^{r} / \partial p_{i}^{r r}$. These give conventional CET supply functions and the elasticity of supply parameter's, $\eta_{i}$ are taken from de Melo and Tarr (1992). A feature of this setting is that goods are homogenous within each region. This keeps the model close to the traditional "Heckscher-Ohlin" setting, within a region, while still allowing for the empirical fact that the same goods are both exported and imported within each region.
} 
provides a parsimonious way of us evaluating the links between economic growth and trade, focusing on the first order terms-of-trade effects of Chinese export growth, and import demand growth, on the terms of trade in China and the USA.

Firms input choices are governed by cost minimization over intermediate inputs and primacy factor inputs. As noted above, the level of aggregation is important in the context of this paper and hence we consider three types of physical capital, Machinery and equipment, Structures and Residential Capital as well as Skilled and Unskilled labour, $L S$ and $L U$, as endogenous variables. The exogenously evolving factors are Land and Resources. In each non-ROW region, commodities are produced by competitive firms under constant returns to scale. described by nested CES unit cost function. The nested CES structure allows us to impose capital-skill complementarity, which is a key idea in the trade-wage literature. ${ }^{19}$ The substitution parameters are thus taken from Krusell et al. Finally, to produce a unit of gross output, firms must also use intermediate inputs in fixed proportions. The outputs of all sectors, except education, are also used as intermediate goods.

\section{A.2 Investment in Physical capital}

The investment demands for each type of capital, and skilled labour are derived from perfect foresight present value maximization problems. The world interest rate, $\rho$, is taken as given by agents so that, through Fisher separation, these investment equations are independent of the consumption decisions.

For each capital good in each non-ROW region, $r \in R$, households choose a sequence of gross investment spending to maximize the net present value of the rental stream. This yields a simple relationship between the investment price index and the rental rate, $\rho+\delta_{k}=u_{k}^{r} / e_{k}^{r}$, where $e_{k}^{r}$ is an investment price index, $\delta_{k}$ is depreciation and $u_{k}^{r}$ is the rental rate for capital good $k$ in region $r$. Thus in the long run equilibrium the size of the capital stock will adjust so that the real rental rate is proportional to the world intrust rate, for a given cost of investment.

\footnotetext{
${ }^{19}$ For examples of this literature see Stokey (1996), Tyers and Yang (2000), Krusell et al (2000) and Winchester and Greenaway (2007).
} 
Thus if costs of investment do not change, and the marginal product of capital rises, then the new equilibrium must have a large capital stock.

\section{A.3 Investment in Education}

We assume that both China and the USA have an education sector that transforms unskilled workers into skilled workers. We define a skilled worker as a worker who possesses a tertiary degree or comparable post-secondary qualifications. At a point in time, the labour force consists of skilled labour, $L S_{t}^{r}$, unskilled labour $L U_{t}^{r}$, and stock of students, $H_{t}^{r}$. We also assume that Mincerian on-the-job training costs are incurred when new graduates enter the workforce. Households then choose the optimal level of schooling to maximize the net present value of labour income, net of on-the-job training costs and direct schooling costs.

On a steady state, yields a constant the ratio of students to the stock of skilled labour, $H^{r} / L S^{r}=b \zeta$. Hence a given percentage increase in China's tertiary enrollment rate will imply an equivalent percentage increase in the skilled labour stock in a new steady state equilibrium. Moreover, in a steady state equilibrium, the skilled labour stock in each non- $R O W$ region, must adjust to satisfy an arbitrage condition that relates returns to skill and unskilled labour to the costs of education and the world interest rate.

\section{A.4 Consumption and Government Spending}

The long run value of consumption, $\chi^{r}, r \in R$ is the level of consumption that is consistent with an exogenous long run zero debt target given: the national income identity; endogenous long run investment rates, and; the government fiscal rule. The optimal steady state consumption path follows from the households' desired net foreign assets to GDP target. We assume this is zero, so that trade is balanced in the long run.

Finally, the government fiscal rule sets the total spending as a ratio of GDP and achieves a balanced budget at each point in time by redistributing any surplus back to the households in the form of a lump sum transfer. The model is thus represented by non-linear equation system of 68 equations and 68 endogenous 
variables. Additional target constraints and endogenous variables are then added to the model in the simulations and these are described below.

The principle data sources for calibraton are are Dimaranan (2006), Barro and Lee (2001), Heston, Summers and Aten (2006), and Brown and Stern (2001). ${ }^{20}$ Calibration also requires choosing the parameters of: the unit expenditure functions for each of the spending aggregates; the unit revenue functions that determine the allocation of outputs across international markets; and the unit cost functions that describe factor input choices by firms. The parameter values are given in an appendix, available from the authors upon request, along with the detailed description of the model. The parameters of the nested CES production functions are taken from Krusell et al (2000) and, consistent with that study, the unit costs functions thus exhibit capital-skill complementarity. The model is solved in Fortran using numerical methods described in Press et al. (1990).

\footnotetext{
${ }^{20}$ On a steady state the total value added by each sector is proportional to total investment spending. Value added flows for the sectors are reconciled with the investment spending data for each physical capital type and also for skilled labour. This requires factor income shares to be scaled to ensure that the relationship between factor incomes and investment spending for the capital holds. In practice, this only required a small adjustment to the value added shares. Likewise trade flow data was scaled to ensure balanced trade exists in the benchmark equilibrium.
} 


\section{References}

Amighini, Alessia, (2005) "China in the International Fragmentation of Production: Evidence from the ICT industry", The European Journal of Comparative Economics, 2, 2, 203-219.

Anderson, Jonathan, (2007) "Is China Export Led?”, UBS Investment Research Asian Focus.

Anderson, James E. and Eric van Wincoop, (2004) “Trade Costs”, NBER Working Paper 10480.

Athukorala, Prema-chandra, (2003) "Product Fragmentation and Trade Patterns in East Asia”, Australian National University, Research School of Asian and Pacific Studies, Working Paper No. 2003/21

Athukorala, Prema-chandra (2009) "The Rise of China and East Asian Export Performance: Is the Crowding-Out Fear Warranted?" The World Economy $32,2,234-266$.

Amiti, Mary and Caroline Freund, (2008) “The Anatomy of China's Export Growth”, The World Bank, Policy Research Working Paper 4628.

Bach, Christian F., Will Martin and Jennifer A. Stevens, (1996) "China and the WTO: Tariff Offers, Exemptions, and Welfare Implications", Review of World Economics, 132, 3, 409-431.

Baier, Scott L. and J.H. Bergstrand, (2001) "The growth of world trade: tariffs, transport costs, and income similarity" Journal of International Economics $53,1,1-27$.

Baldwin, Richard and Fréderic Robert-Nicoud, (2006) "Offshoring and Globalisation: What is New about the New Paradigm?", Graduate Institute of International Studies, Geneva; London School of Economics 24.

Barro, R. J. and J. W. Lee, (2001) "International Data on Educational Attainment: Updates and Implications", Oxford Economic Papers, 53, 3, 541-563. 
Bergstrand, J.H., (1985) "The gravity equation in international trade: Some microeconomic foundations and empirical evidence", Review of Economics and Statistics 67,3, 474-481.

Bosworth, Barry and Susan M. Collins, (2008) “Accounting for Growth: Comparing China and India", Journal of Economic Perspectives, 22, 1, 4566.

Branstetter, Lee and Nicholas Lardy, (2006) "China's Embrace Of Globalization", NBER Working Paper 12373.

Bussière, Matthieu and Bernd Schnatz, (2009) "Evaluating China's Integration In World Trade With A Gravity Model Based Benchmark”, Open Economies Review, 20, 1, 85-111.

Chow, G. C., (2002) “China's Economic Transformation”, Malden, MA, Blackwell Publishers.

Deardorff, A. (2001), "Fragmentation in Simple Trade Models", North American Journal of Economics and Finance, 12, 121-137.

de Melo, J. and D. Tarr (1992) “A general equilibrium Analysis of U.S. Foreign Policy” MIT Press Cambridge, MIT.

Dimaranan, Betina V., (2006) "Global Trade, Assistance, and Production: The GTAP 6 Data Base”, Center for Global Trade Analysis, Purdue University.

Fleisher, B. M. and X. Wang, (2004) "Skill Differentials, Return to Schooling, and Market Segmentation in a Transition Economy: The Case of Mainland China", Journal of Development Economics, 73, 1, 315-328.

Fleisher, B. M. and X. Wang, (2005) "Returns to Schooling in China Under Planning and Reform", Journal of Comparative Economics33, 2, 265-277.

Fleisher, B. M., Y. Hu and H. Li, (2006) "Economic Transition, Higher Education and Worker Productivity in China", Mimeo. 
Fogel, R. W., (2006) "Why China is Likely to Achieve its Growth Objectives", NBER Working Paper No. 12122, NBER.

Freeman, Richard B., (2007) The Challenge of the Growing Globalization of Labor Markets to Economic and Social Policy. In: Eva A. Paus (Ed), Global Capitalism Unbound: Winners and Losers from Offshore Outsourcing, NY: Palgrave MacMillan.

Graham, Bryan S. and Jonathan Temple, (2006) "Rich nations, poor nations: how much can multiple equilibria explain?" Journal of Economic Growth, 11, 1, $5-41$.

Hannum, Emily, Jere Behrman, Meiyan Wang and Jihong Liu, (2007) Education in the Reform Era. In: Loren Brandt and Thomas Rawski (Eds), China's Great Economic Transformation, Cambridge University Press.

Hansen, Gary D. and Edward C. Prescott, (2002) "Malthus to Solow," American Economic Review, 92, 4, 1205-1217.

Hayashi, Fumio and Edward C. Prescott (2008) "The Depressing Effect of Agricultural Institutions on the Prewar Japanese Economy" Journal of Political Economy, 116, 4.

Heckman, J. J., (2005), “China’s Human Capital Investment”, China Economic Review, 16, 50-70.

Heckman, J. J., and X. Li, (2004) "Selection Bias, Comparative Advantage and Heterogeneous Returns to Education: Evidence from China in 2000", Pacific Economic Review, 9, 3, 155-171.

Heston, Alan Robert Summers and Bettina Aten (2006) "Penn World Tables Version 6.2", Center for International Comparisons of Production, Income and Prices at the University of Pennsylvania, September 2006.

Hummels, David, (2007) "Transportation Costs and International Trade in the Second Era of Globalization", Journal of Economic Perspectives, 21, 3, 131-154. 
Islam, N., E. Dai, and H. Sakamoto, (2006) "Role of TFP in China's Growth", Asian Economic Journal, 20, 2, 127-159.

Jones R. W. and H. Kierzkowski, (1990) The Role of Services in Production and International Trade: A Theoretical Framework. In: Jones R. W. and Krueger A. O. (Eds), The Political Economy of International Trade: Essays in Honor of Robert E. Baldwin, Blackwell, Cambridge, MA.

Knight, John and Li Shi, (1996) "Educational Attainment and the Rural-Urban Divide in China”, Oxford Bulletin of Economics and Statistics, 58, 1, 83117.

Krugman, Paul, (2008) “Trade and Wages Reconsidered”, Paper presented at the Brookings Panel on Economic Activity.

Krusell, Per, L. Ohanian, José-Víctor Ríos-Rull, and Giovanni Violante, (2000) “Capital-Skill Complementarity and Inequality”, Econometrica, 68, 10291053.

Lawrence, Robert, (2008) "Blue-collar Blues: Is Trade to Blame for Rising US Income Inequality?", The Petersen Institute for International Economics: Washington, DC.

Lardy, Nicholas, R. (2003) Trade Liberalization and its Role in Chinese Economic Growth, International Monetary Fund and National Council of Applied Economic Research Conference A Tale of Two Giants: India's and China's Experience with Reform and Growth New Delhi, November 14-16

Li, Yao, John Whalley, Shunming Zhang and Xiliang Zhao, (2008) "The Higher Educational Transformation of China and Its Global Implications", NBER Working Paper 13849.

Min, Y., (2005), Historical Perspectives and Contemporary Challenges: The Case of Chinese Universities, Unpublished Manuscript, Centre of Chinese Education, University of Columbia. 
OECD, (2002), Indicators of Internationalization and Trade in Post Secondary Education, Center for Education Research and Innovation, Paris.

Pavcnik, Nina, (2003) "What Explains Skill Upgrading in Less Developed Countries?", Journal of Development Economics, 71, 311-328.

Parente, Stephen L., Richard Rogerson and Randall Wright (2000) "Homework in Development Economics: Household Production and the Wealth of Nations", Journal of Political Economy, 108, 4.

Perkins, F. C., (1997) “Export Performance and Enterprise Reform in China's Coastal Provinces", Economic Development and Cultural Change, 45, 3, 501-539.

Rodrik, Dani, (2006) “What's So Special About China's Exports?”, China and The World Economy, 4 5, 1-19.

Rumbaugh, Thomas and Nicholas Blancher, (2004) International Trade and the Challenges of WTO Accession. In Prasad, Eswar (Ed), China's Growth and Integration into the World Economy: Prospects and Challenges, IMF Occasional Paper 232, Washington, StateDC.

Ruoen, Ren, (1995) “China's Economic Performance in International Perspective” Manuscript. Paris: OECD Development Centre.

Schott, Peter K., (2006) “The Relative Revealed Competitiveness of China's Exports to the United States vis à vis Other Countries in Aisa, the Caribbean, Latin America and the OECD, Occasional Paper 39, InterAmerican Development Bank, Integration and Regional Programs Development.

Stokey N.L., (1996) "Free Trade, Factor Returns, and Factor Accumulation", Journal of Economic Growth, 1, 4, 421-447.

The Economist, (2006) "Asia and the World Economy", October 19

The Economist, (2008) "Will The Developing World Escape Unscathed from an American Recession", March 6. 
Tsang, M., (2001) "Intergovernmental Grants and the Financing of Compulsory Education in China", Center on Chinese Education Publication, A1, Teachers College, Columbia University.

Tyers, Rod, and Y. Yang, (2000) "Capital-skill Complementarity and Wage Outcomes Following Technical Change in a Global Model", Oxford Review of Economic Policy, 16, 3, 23-41.

UNESCO, (2002) "Financing Education - Investments and Returns: Analysis of the World Education Indicators", UNESCO Institute for Statistics and OECD, World Education Indicator Programme.

Winchester, Niven and David Greenaway, (2007) "Rising Wage Inequality and Capital-Skill Complementarity", Journal of Policy Modeling, 29, 1, 41-54.

Woo, Wing Thye (1998) "Chinese Economic Growth: Sources and Prospects, in Michel Fouquin and Francoise Lemoine (ed.), The Chinese Economy, Economica, London.

Yi, Kei-Mu, (2003) "Can Vertical Specialization Explain the Growth of World Trade?" Journal of Political Economy, 111, 1, 52-102.

Young, Alwyn, (2003) "Gold into Base Metals: Productivity Growth in the People's Republic of China during the Reform Period", Journal of Political Economy, 11, 1221-1261.

Zhang, X., (2001) The Impact of Tariff Reduction on the Growth of the Chinese Economy. In Lloyd, P. and Zhang, X. (Eds), Models of the Chinese Economy, Edward Elgar, Cheltenham, UK, 151-177.

Zhang, W., (2006) “China's Higher Education Trade and the Impact of the WTO/GATT Liberalization”, $\mathrm{PhD}$ thesis, University of Columbia. 
Table 1. GDP per Worker Growth Rates in China

\begin{tabular}{|ccccc|}
\hline & Official & $\begin{array}{c}\text { Bosworth and } \\
\text { Collins } \\
\text { Alternative }\end{array}$ & $\begin{array}{c}\text { Bosworth and } \\
\text { Collins Preferred }\end{array}$ & $\begin{array}{c}\text { Penn World } \\
\text { Tables* }\end{array}$ \\
\hline $1979-2004$ & 8.05 & 6.71 & 7.30 & 7.96 \\
$1979-1995$ & 7.64 & 5.64 & 6.41 & 8.02 \\
$1995-2004$ & 8.96 & 8.53 & 8.92 & 8.08 \\
\hline
\end{tabular}

Source: Bosworth and Collins (2008) and Penn World Tables 6.2

* Data For Penn World Tables is 1979-2003 
Table 2. Values Shares of Merchandise Exports

\begin{tabular}{|lccc|}
\hline & $\begin{array}{c}\text { Export Share } \\
1990\end{array}$ & $\begin{array}{c}\text { Export Share } \\
1995\end{array}$ & $\begin{array}{c}\text { Export Share } \\
2005\end{array}$ \\
\hline Agriculture and Raw Materials & 0.14 & 0.09 & 0.03 \\
Minerals & 0.10 & 0.04 & 0.03 \\
Low-Tech Manufacturing & 0.36 & 0.37 & 0.24 \\
Intermediate Manufacturing & 0.14 & 0.17 & 0.14 \\
Durables & 0.26 & 0.33 & 0.56 \\
\hline Source: Comtrade & &
\end{tabular}

Source: Comtrade 
Table 3. China's Tariff Rates: $1995-2005$

\begin{tabular}{|lcccc|}
\hline & $\begin{array}{c}\text { Tariff on } \\
\text { ROW, 1995 }\end{array}$ & $\begin{array}{c}\text { Tariff on } \\
\text { USA, 1995 }\end{array}$ & $\begin{array}{c}\text { Tariff on } \\
\text { ROW, 2004 }\end{array}$ & $\begin{array}{c}\text { Tariff on } \\
\text { USA, 2004 }\end{array}$ \\
\hline Agriculture and Raw Materials & 48.5 & 52.0 & 18.4 & 17.0 \\
Minerals & 22.3 & 22.6 & 7.9 & 7.8 \\
Low-Tech Manufacturing & 49.3 & 34.8 & 10.9 & 7.4 \\
Intermediate Manufacturing & 22.9 & 22.6 & 7.4 & 7.4 \\
Durables & 28.2 & 29.7 & 8.5 & 8.6 \\
\hline
\end{tabular}

Source: Authors calculations from Trade and Protection database, World Bank. 
Table 4: Summary of Simulations

\begin{tabular}{|c|c|c|c|c|c|}
\hline & & Instruments & Constraints & Target Variable & Target Value \\
\hline$s 1$ & Neutral productivity growth & $A_{S}, A_{u}$ & $\hat{A}_{S}=\hat{A}_{U}$ & $G D P$ & $80.8 \%$ \\
\hline$s 2$ & $\begin{array}{l}\text { Neutral productivity growth and uniform tradables sector } \\
\text { growth }\end{array}$ & $\begin{array}{l}A_{S}, A_{u} \\
\lambda_{1,1} \ldots \lambda_{1,6} \\
\lambda_{3,1 \ldots} \lambda_{3,6}\end{array}$ & $\begin{array}{l}\hat{A}_{S}=\hat{A}_{U} \\
\lambda_{i 1}=\lambda_{i 3}=\bar{\lambda}, \forall i\end{array}$ & $\begin{array}{l}\text { GDP } \\
\text { Exports/GDP }\end{array}$ & $\begin{array}{l}80.8 \% \\
59.1 \%\end{array}$ \\
\hline s3 & $\begin{array}{l}\text { Neutral productivity growth and sector specific growth in all } \\
\text { tradables sectors. }\end{array}$ & $\begin{array}{l}A_{S}, A_{u} \\
\lambda_{1,1} \ldots \lambda_{1,6} \\
\lambda_{3,1} \ldots \lambda_{3,6}\end{array}$ & $\hat{A}_{S}=\hat{A}_{U}$ & $\begin{array}{l}\text { GDP } \\
\text { Exports/GDP } \\
\text { Ag. export share } \\
\text { Mineral export share } \\
\text { Low-tech export share } \\
\text { Int. Manu export share } \\
\text { Durables export share }\end{array}$ & $\begin{array}{r}80.8 \% \\
59.1 \% \\
-62.4 \% \\
-39.2 \% \\
-34.7 \% \\
-15.3 \% \\
69.3 \%\end{array}$ \\
\hline$s 4$ & $\begin{array}{l}\text { Neutral productivity growth and sector specific growth in all } \\
\text { tradables sectors and exogenous tariff reductions for all } \\
\text { Chinese tariffs on imports to China }\end{array}$ & $\begin{array}{l}A_{S}, A_{u}, \\
\lambda_{1,1 \ldots} \lambda_{1,6}, \\
\lambda_{3,1 \ldots} \lambda_{3,6}, \\
\tau_{21, i}, \quad i=1,6, \\
\tau_{23, i,} \quad i=1,6\end{array}$ & $\hat{A}_{S}=\hat{A}_{U}$ & $\begin{array}{l}\text { GDP } \\
\text { Exports/GDP } \\
\text { Ag. export share } \\
\text { Mineral export share } \\
\text { Low-tech export share } \\
\text { Int. Manu export share } \\
\text { Durables export share }\end{array}$ & $\begin{array}{r}80.8 \% \\
59.1 \% \\
-62.4 \% \\
-39.2 \% \\
-34.7 \% \\
-15.3 \% \\
69.3 \%\end{array}$ \\
\hline$s 5$ & $\begin{array}{l}\text { Education subsidies increase to meet education student } \\
\text { enrolment targets. }\end{array}$ & $s$ & & Stock of Students & $85.0 \%$ \\
\hline s6 & $\begin{array}{l}\text { Neutral productivity growth and sector specific growth in all } \\
\text { tradables sectors and exogenous tariff reductions for all } \\
\text { Chinese tariffs on imports to China and Education subsidies } \\
\text { increase to meet education student enrolment targets. }\end{array}$ & $\begin{array}{l}\text { Exogenous changes in } \\
A_{S}, A_{u}, \\
\lambda_{1,1 \ldots} \lambda_{1,6}, \lambda_{3,1 \ldots}, \lambda_{3,6}, \\
\tau_{21, i}, \quad i=1,6, \\
\tau_{23, i}, \quad i=1,6 . \\
\text { Endogenous change in } s\end{array}$ & & Stock of students & $85.0 \%$ \\
\hline
\end{tabular}


Table 5: Alternative Growth Patterns in China (\% change)

\begin{tabular}{|c|c|c|c|c|}
\hline & $\begin{array}{c}\text { Real GDP } \\
\text { Target }\end{array}$ & $\begin{array}{l}\text { Real GDP } \\
\text { and X/GDP }\end{array}$ & $\begin{array}{c}\text { Real GDP, } \\
\text { X/GDP and } \\
\text { Sector Trade } \\
\quad \text { Shares } \\
\text { s3 } \\
\end{array}$ & $\begin{array}{c}s 3 \& \\
\text { unilateral } \\
\text { Tariff } \\
\text { Removal } \\
s 4\end{array}$ \\
\hline Real GDP per capita China & 80.8 & 80.8 & 80.8 & 80.8 \\
\hline Exports relative to GDP & -25.9 & 59.1 & 59.1 & 59.1 \\
\hline Real Skilled wages & 31.3 & 24.6 & 22.8 & 28.9 \\
\hline Real Unskilled wages & 86.3 & 57.2 & 51.4 & 70.3 \\
\hline Real Consumption per worker & 72.5 & 79.9 & 78.1 & 61.4 \\
\hline Machinery and Equipment & 85.0 & 98.6 & 107.3 & 124.0 \\
\hline Structures & 88.8 & 84.5 & 88.7 & 108.2 \\
\hline Residential Capital & 96.1 & 117.0 & 115.9 & 94.1 \\
\hline Skilled Labour & 18.1 & 45.7 & 53.0 & 49.4 \\
\hline Unskilled labour & -0.5 & -1.3 & -1.5 & -1.4 \\
\hline Tertiary Enrolments & 18.1 & 45.7 & 53.0 & 49.4 \\
\hline Terms of Trade & -10.7 & -39.5 & -39.5 & -31.2 \\
\hline Price of Traded to Non-Traded & -0.7 & -3.8 & -4.4 & -3.0 \\
\hline Inverse Trade Costs Index & 0.0 & 93.2 & 99.3 & 38.8 \\
\hline Labour Productivity Index & 107.7 & 37.9 & 29.1 & 55.0 \\
\hline \multicolumn{5}{|l|}{ Industry Quantity Index } \\
\hline Agriculture & 75.0 & 20.5 & 7.0 & 22.3 \\
\hline Minerals & 102.2 & 27.5 & 34.3 & 85.8 \\
\hline Low Tech Manufacturing & 98.3 & 148.0 & 34.0 & 51.0 \\
\hline Intermediate Manufacture & 99.3 & 45.4 & 60.7 & 102.7 \\
\hline Durables & 92.8 & 65.2 & 147.2 & 177.5 \\
\hline Traded Services & 106.6 & 85.9 & 90.8 & 111.6 \\
\hline Construction & 90.5 & 81.8 & 84.4 & 100.4 \\
\hline Non Traded Services & 90.0 & 75.4 & 72.8 & 88.5 \\
\hline Public & 91.9 & 73.3 & 71.7 & 88.4 \\
\hline Residential & 70.2 & 72.6 & 72.0 & 59.1 \\
\hline Education & 18.1 & 45.7 & 53.0 & 49.4 \\
\hline \multicolumn{5}{|l|}{ Trade Share / Target } \\
\hline Agriculture & 2.0 & 1.3 & 1.0 & 1.0 \\
\hline Minerals & 1.7 & 1.2 & 1.0 & 1.0 \\
\hline Low Tech Manufacturing & 1.5 & 2.2 & 1.0 & 1.0 \\
\hline Intermediate Manufacture & 1.2 & 0.9 & 1.0 & 1.0 \\
\hline Durables & 0.6 & 0.5 & 1.0 & 1.0 \\
\hline
\end{tabular}


Table 6: Impact of Chinese Economic Growth on the USA (\% change)

\begin{tabular}{|c|c|c|c|c|}
\hline & $\begin{array}{l}\text { Real GDP } \\
\text { Target } \\
\\
s 1\end{array}$ & $\begin{array}{l}\text { Real GDP } \\
\text { and X/GDP } \\
s 2 \\
\end{array}$ & $\begin{array}{c}\text { Real GDP, } \\
\text { X/GDP and } \\
\text { Sector Trade } \\
\text { Shares } \\
\text { s3 } \\
\end{array}$ & $\begin{array}{c}3 \& \\
\text { unilateral } \\
\text { Tariff } \\
\text { Removal } \\
s 4 \\
\end{array}$ \\
\hline Real GDP per capita USA & 0.4 & 3.8 & 4.5 & 2.9 \\
\hline Exports relative to GDP & 3.2 & 32.9 & 33.1 & 21.9 \\
\hline Real Skilled wages & 0.3 & 2.6 & 3.0 & 2.0 \\
\hline Real Unskilled wages & 0.3 & 2.7 & 3.2 & 2.1 \\
\hline Real Consumption per worker & 0.3 & 3.5 & 4.0 & 2.6 \\
\hline Machinery and Equipment & 0.6 & 6.1 & 8.3 & 5.4 \\
\hline Structures & 0.5 & 5.6 & 7.2 & 4.6 \\
\hline Residential Capital & 0.4 & 4.1 & 4.7 & 3.0 \\
\hline Skilled Labour & 0.2 & 1.7 & 1.1 & 0.7 \\
\hline Unskilled labour & -0.1 & -0.5 & -0.3 & -0.2 \\
\hline Tertiary Enrolments & 0.2 & 1.7 & 1.1 & 0.7 \\
\hline Terms of Trade & 1.2 & 8.6 & 10.7 & 7.7 \\
\hline Price of Traded to Non Traded & -0.3 & -3.0 & -3.5 & -2.3 \\
\hline \multicolumn{5}{|l|}{ Industry Outputs } \\
\hline Agriculture & 1.4 & 32.8 & 40.5 & 24.6 \\
\hline Minerals & 1.5 & 19.0 & 21.3 & 12.7 \\
\hline Low Tech Manufacturing & 0.0 & -42.2 & 17.3 & 18.3 \\
\hline Intermediate Manufacture & -0.9 & 5.6 & -1.0 & -2.4 \\
\hline Durables & -0.5 & 3.5 & -43.6 & -31.4 \\
\hline Traded Services & 0.3 & 3.3 & 4.0 & 2.6 \\
\hline Construction & 0.3 & 3.7 & 4.8 & 3.1 \\
\hline Non Traded Services & 0.2 & 2.4 & 2.4 & 1.5 \\
\hline Public & 0.2 & 2.2 & 2.8 & 1.8 \\
\hline Residential & 0.3 & 2.7 & 3.0 & 2.0 \\
\hline Education & 0.2 & 1.7 & 1.1 & 0.7 \\
\hline
\end{tabular}


Table 7: Impact of Education Policies and Growth on China (\% change)

\begin{tabular}{|c|c|c|}
\hline & $\begin{array}{l}\text { Education } \\
\text { Subsidies }\end{array}$ & $\begin{array}{l}\text { Education } \\
\text { Subsidies and } \\
\text { Prod. Growth } \\
\text { (relative to } s 4\end{array}$ \\
\hline & $s 5$ & s6 \\
\hline Real GDP per capita & 6.8 & 2.4 \\
\hline Exports relative to GDP & -2.6 & -0.5 \\
\hline Real Skilled wages & -51.1 & -22.3 \\
\hline Real Unskilled wages & 3.8 & 1.3 \\
\hline Real Consumption per worker & 1.6 & 0.6 \\
\hline Machinery and Equipment & 10.7 & 3.5 \\
\hline Structures & 11.7 & 4.0 \\
\hline Residential Capital & 5.9 & 2.0 \\
\hline Skilled Labour & 85.0 & 23.8 \\
\hline Unskilled labour & -2.5 & -1.1 \\
\hline Tertiary Enrolments & 85.0 & 23.8 \\
\hline Terms of Trade & -1.0 & -0.5 \\
\hline Price of Traded to Non-Traded & -0.2 & -0.1 \\
\hline Inverse Trade Costs Index & 0.0 & 0.0 \\
\hline Labour Productivity Index & 0.0 & 0.0 \\
\hline Tax Rate on Skilled Labour & 0.0 & 0.0 \\
\hline Education Subsidy (level) & 91.8 & 51.9 \\
\hline \multicolumn{3}{|l|}{ Industry Outputs } \\
\hline Agriculture & 1.2 & 0.1 \\
\hline Minerals & 10.2 & 4.0 \\
\hline Low Tech Manufacturing & 5.9 & 3.3 \\
\hline Intermediate Manufacture & 9.3 & 3.4 \\
\hline Durables & 9.3 & 2.6 \\
\hline Traded Services & 10.9 & 3.5 \\
\hline Construction & 10.0 & 3.5 \\
\hline Non Traded Services & 7.8 & 2.9 \\
\hline Public & 10.4 & 3.7 \\
\hline Residential & 1.9 & 0.8 \\
\hline Education & 85.0 & 23.8 \\
\hline
\end{tabular}


Table 8: Impact Of Chinese Economic Growth on the USA (\% change)

\begin{tabular}{|lcc|}
\hline & $\begin{array}{c}\text { Education } \\
\text { Subsidies }\end{array}$ & $\begin{array}{c}\text { Education } \\
\text { Subsidies \& } \\
\text { Growth } \\
\end{array}$ \\
& $s 5$ & $s 6$ \\
\hline Real GDP per capita USA & 0.0 & 0.1 \\
Exports relative to GDP & 0.4 & 0.5 \\
Real Skilled wages & 0.0 & 0.0 \\
Real Unskilled wages & 0.0 & 0.0 \\
Real Consumption per worker & 0.0 & 0.1 \\
Machinery and Equipment & 0.1 & 0.1 \\
Structures & 0.1 & 0.1 \\
Residential Capital & 0.1 & 0.1 \\
Skilled Labour & 0.0 & 0.0 \\
Unskilled labour & 0.0 & 0.0 \\
Tertiary Enrolments & 0.0 & 0.0 \\
Terms of Trade & 0.2 & 0.1 \\
Price of Traded to Non Traded & 0.0 & -0.1 \\
& & \\
Industry Outputs & & \\
Agriculture & 0.3 & 0.1 \\
Minerals & -0.1 & 0.5 \\
Low Tech Manufacturing & 0.4 & 0.0 \\
Intermediate Manufacture & -0.2 & 0.0 \\
Durables & -0.3 & 0.1 \\
Traded Services & 0.0 & 0.1 \\
Construction & 0.0 & 0.1 \\
Non Traded Services & 0.0 & 0.1 \\
Public & 0.0 & 0.0 \\
House & 0.0 & 0.0 \\
Education & 0.0 & 0.0 \\
\hline
\end{tabular}


Figure 1: Trade as a Fraction of GDP in China

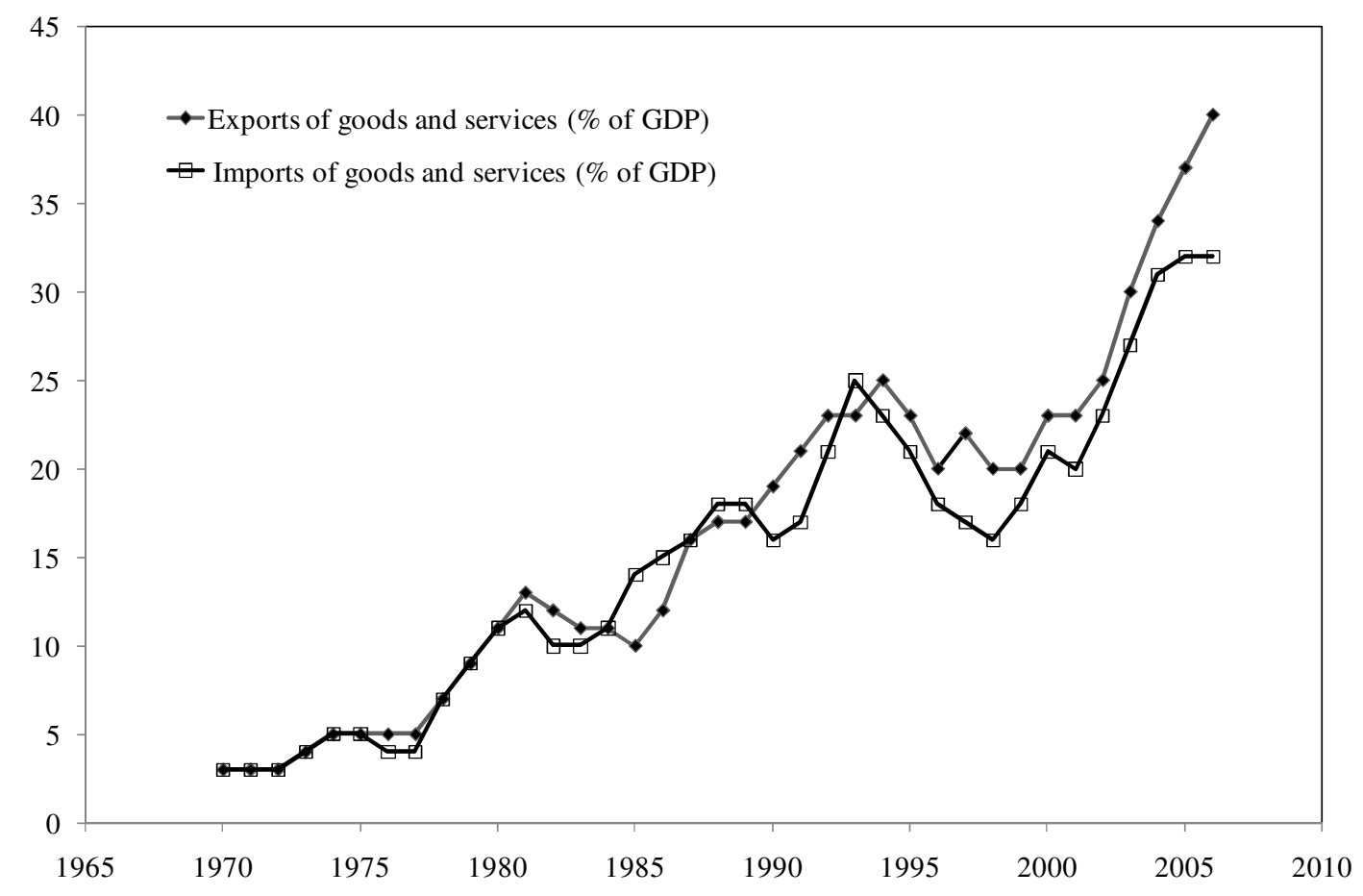

Source World Bank, World Development Indicators 
Figure 2: Tertiary Student Enrolments as a Fraction of the Population 15-65

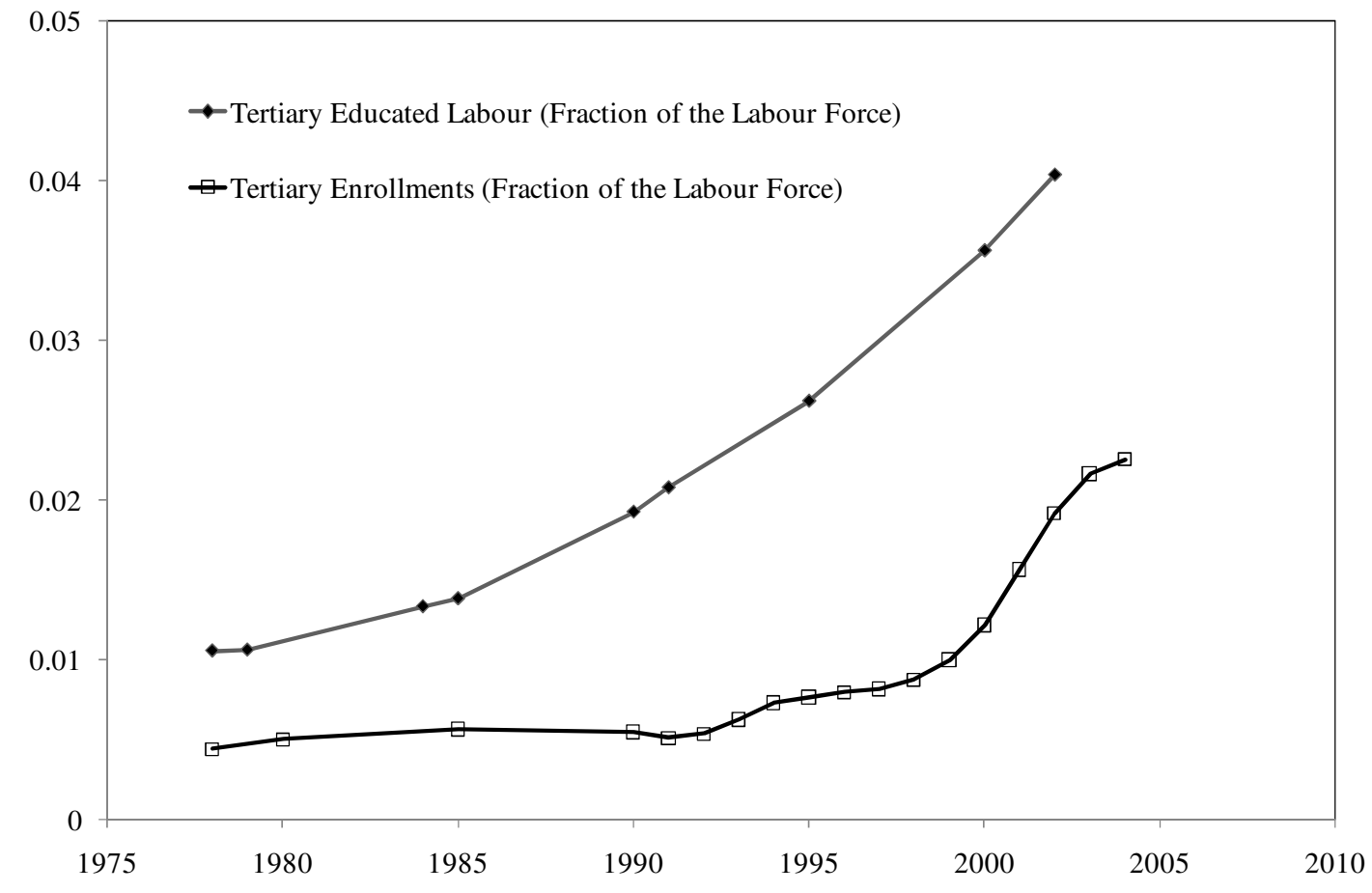

Source: China Statistical Yearbook 2005,Penn World Tables 6.2 


\section{Appendix: Model Details (for Referee)}

This appendix describes the model described in the text. The world economy consists of three regions $\bar{R}=\{1,2,3\}$ where $1=U S A, 2=$ China and $3=$ Rest -of-World $($ ROW $)$. In the ROW outputs and prices are exogenous but the export supplies of commodities to other regions are endogenous. The non-ROW, $\bar{R}=\{1,2\}$, regions can face an infinitely elastic demand for their exports from the $R O W$. There are eleven goods produced in 11 sectors denoted by the set $I=\{1, \ldots, 11\}$. Of these the first six elements are traded goods, $I_{T}=\{1, \ldots, 6\}$ and the last five are non-traded, $I_{N}=\{7, \ldots, 11\}$

\subsection{Technology}

Firms in each non-ROW region, $R$, use intermediate goods and primary factors of production to produce a real gross output flow, $g_{i}^{r}$, in each industry $i$. Suppressing region superscripts, the inputs of the valued added aggregating vector are the elements of the set of factors, $\bar{K}=\{1, \ldots, 7\}$ where, respectively, 1 = Machinery and Equipment, 2 = Structures, $3=$ Residential Capital, $4=$ Skilled labor, $5=$ Unskilled labor, $6=$ Land, and $7=$ Resources. We label these factors $V_{k, t}, k \in \bar{K}$. The first three factors are all types of reproducible physical capital, and are denoted by the subset $K=\{1, \ldots, 3\}$, The sectoral allocation of these factors for each sector $i$ is likewise denoted as $V_{k, i, t}, k \in \bar{K}$. It will be also convenient to occasionally refer to aggregate skilled and unskilled labor endowments as $V_{4}=L S$ and $V_{5}=L U$.

As in standard growth models we assume that there is exogenous productivity growth associated with labor and other exogenously supplied factors. We denote the levels of factor augmenting productivity for factor $k$, at time $t$, as $A_{k, t}$.

Suppressing time subscripts, these effective and actual primary inputs are combined in a time independent value added function

$$
v_{i}=v_{i}\left(V_{1, i}, \ldots, V_{7, i}\right)
$$

These inputs are measured in effective units. Dual to this value added aggregator, $v_{i}$, is a cost function 


$$
c_{i}=c_{i}(\hat{\mathbf{w}})
$$

where $\hat{\mathbf{w}}_{i}$ is the vector of returns $\hat{\mathbf{w}}_{i}=\left\{w_{1}, \ldots, w_{7}\right\}$, and the circumflex denotes effective units so that $\hat{w}_{k}=w_{k} / A_{k}, k \in K$. As noted in the text, we assume this cost function is a nested CES form.

$$
c_{i, t}(w)=\left(\delta_{\theta} \theta_{i, t}^{\sigma}+\delta_{L U} \hat{w}_{L U, t}^{\sigma}+\sum_{k \in N} \delta_{k} \hat{w}_{k, t}^{\sigma}\right)^{\frac{1}{\sigma}},
$$

where,

$$
\theta_{i, t}=\left(\sum_{k \in K} \delta_{k} w_{k, t}^{v}+\delta_{L S} \hat{w}_{L S, t}^{v}\right)^{\frac{1}{v}}
$$

Intermediate goods and the intermediate and value added aggregates are combined with fixed coefficients. Let $M_{i}$ denote an intermediate input aggregate in each industry $i$. Then

$$
M_{i}=\min _{j}\left[\frac{Y_{j, i}}{a_{j, i}}\right]
$$

where $a_{j, i}$ is a technological parameter and $Y_{j, i}$ is the quantity of good $j$ used as an input in sector $i$.

The real gross output flow $g_{i}$, in each industry $i$ is then

$$
g_{i}=\min _{i}\left[M_{i}, v_{i}\right]
$$

For the ROW region output is an exogenously growing "endowment", $V_{w, t}$, which grows at rate $V_{w, t+1} / V_{w, t}=1+\gamma$, where $\gamma$ is a constant. It follows, therefore, that on a steady state the non- $R O W$ regions must also be growing at rate $1+\gamma$.

\subsection{Commodity Supply}

In the non-traded goods industries gross output is simply a scalar. In the traded goods industries gross output is an aggregate of three destination specific goods - one good destined for the home market, and two others for the other respective export regions. Given the set of regions, $\bar{R}=\{1,2,3\}$, the gross output for traded good sector, $i$, is, 


$$
g_{i}^{r}=g_{i}^{r}\left(x_{i}^{r, 1}, x_{i}^{r, 2}, x_{i}^{r, 3}\right)
$$

where $g_{i}^{r}, r \in \bar{R}$ is convex and linearly homogenous in its arguments and the $x_{i}^{r, j}$ refer to the supply of good $i$ from region $r$ to region $j \in \bar{R}, r \in \bar{R}$. Dual to these grows output functions are the revenue functions given by, $\phi_{i}^{r}\left(p_{i}^{r, 1}, p_{i}^{r, 2}, p_{i}^{r, 3}\right) g_{i}^{r}$ for $r \in \bar{R}$, where the $p_{i}^{r, j}$ are producer prices for firms in region $r \in \bar{R}$ received in each market, $j$. Since goods in each market are homogenous, irrespective of the source region, the producer price for a firm in each region $r$ selling in region $j$, must satisfy the conditions $p_{i}^{r, j}\left(1+\tau^{j, r}\right)=q_{i}^{j}$ where $\tau^{j, r}$ are the tariff rates by region $j$ on each region $r$ 's exports. ${ }^{21}$ The revenue function is assumed to be of the Constant Elasticity of Transformation (CET) form.

$$
\phi_{i}^{r}=\mu_{i}^{r}\left[\sum_{j=1}^{3} \delta_{i, j}^{r}\left(\lambda_{i, j}^{r} p_{i, j}\right)^{\eta_{i}}\right]^{\frac{1}{\eta_{i}}}, r \in \bar{R}, j \in \bar{R}
$$

The regional supply functions are obtained from this revenue function using the envelope theorem. For the non-ROW regions, $R=\{1,2\}$, the unit supply functions to each are equal to $x_{i}^{r, j}=\left(\partial \phi_{i}^{r} / \delta p_{i}^{r j}\right) g_{i}^{r}$. For $r \neq j$ these unit supply functions are export supply functions. For the ROW region $x_{i}^{3 j}=\left(\partial \phi_{i}^{3} / \delta p_{i}^{3 j}\right) \psi V_{W}$, for $j \in R$ where $\psi$ is a parameter that scales exports proportionally to world GDP.

\subsection{Commodity Demands}

Given the Leontief technology for intermediate goods, intermediate demands for each sector $i$, and each region $R \in\{1,2\}$, are given by,

$$
\sum_{j} a_{i, j}^{r} g_{j}^{r}
$$

Final demands for each commodity, except education services, are determined by several CES aggregate expenditure functions. There are two agents in each region, a government and a representative household. The households make education and investment decisions as well as consume. The set of final goods spending is given by $Z=\{1, \ldots, 5\}$ where elements $1 \ldots 3$ represent

\footnotetext{
${ }^{21}$ For clarity this ignores commodity taxes which are included in the model.
} 
investment spending on three three types of physical capital, 4 represents consumption spending and 5 is Government spending. For each spending type in each region, there is a constant elasticity of substitution (CES) unit expenditure index function, given by,

$$
e_{z}^{r}\left(\mathbf{q}^{r}\right)
$$

where $\mathbf{q}^{r}$ is the vector of consumer prices for each region. Shepherd's Lemma gives a vector of commodity demands generated by each component of final demand

$$
d_{z, i}^{r}=\frac{\partial e_{z}^{r}}{\partial q_{i}^{r}} Q_{z}^{r}
$$

where $Q_{z}^{r}$ is the real quantity index for each of these spending types. Thus $Q_{z}^{r} e_{z}^{r}$ is the total spending on each element of the list of spending types $z$. For the subset of spending types that that refer to investment spending $z \in\{1,2,3\}$, the value of $e_{z}^{r}$ determines the investment price index.

\subsection{Aggregate Investment demand}

Except for government spending, the level of spending on each type of investment is determined through inter-temporal maximization decisions by households. Investment spending is determined by households who choose an optimal investment plan to maximize the net present value of the rental stream of the asset, given an adjustment cost function $C\left(Q_{k}^{r}, V_{k}^{r}\right), k \in K$.

As discussed in the text the investment plan is the solution to the Fisher problem of choosing a sequence of gross investment spending to maximize the Lagrangian

$$
\begin{aligned}
& L_{k}^{r}=\sum_{t=0}^{\infty}\left(\frac{1}{1+\rho}\right)^{t}\left[u_{k, t} V_{k, t}^{r}-u_{k, t} C_{k}^{r}\left(Q_{k, t}^{r}, V_{k, t}^{r}\right)-e_{k, t}^{r} Q_{k, t}^{r}\right. \\
& \left.-\Pi_{k, t+1}^{r}\left(V_{k, t+1}^{r}-Q_{k, t}^{r}-\left(1-\delta_{k}\right) V_{k, t}^{r}\right)\right]
\end{aligned}
$$

where $k \in K, e_{k}^{r}$ are the investment cost indices and $u_{k}^{r}$ refer to after factor tax rentals on physical capital $k$ in region $R$. Assuming quadratic adjustment costs

$$
C_{k}^{r}\left(Q_{k, t}^{r}, V_{k, t}^{r}\right)=\frac{\beta_{k,}^{r}\left(Q_{k, t}^{r}-(\delta+\gamma) V_{k, t}^{r}\right)^{2}}{V_{k, t}^{r}}
$$


where $\beta_{k}$ is a parameter, $\gamma$ is the steady state growth rate of the economy, $\delta_{k}$ is the retirement rate for skilled labor, we obtain an investment demand equation for each asset type $k$, as

$$
\frac{Q_{k, t}^{r}}{V_{k, t}^{r}}=\frac{\Pi_{k, t}^{r}-e_{k, t}^{r}}{\beta_{k, t}^{r} u_{k, t}^{r}}+\gamma+\delta_{k}
$$

for $k \in K$. The Lagrange multipliers, $\Pi_{k, t}^{r}$, have the usual interpretation as the shadow price of a unit of capital of type $k$. For reference, the shadow price of the stock evolves according to the following dynamic equation,

$$
\Pi_{k, t}^{r}=\frac{1}{1+\rho}\left[\left(u_{k, t+1}^{r}-u_{k, t+1}^{r} C_{k, 2}^{r}\left(Q_{k, t+1}^{r}, V_{k, t+1}^{r}\right)+\left(1-\delta_{k}\right) \Pi_{k, t+1}^{r}\right]\right.
$$

where $C_{k, 2}^{r}\left(Q_{k, t+1}^{r}, V_{k, t+1}^{r}\right)$ refers to the derivative of the adjustment cost function with respect to the second argument, $V_{k, t+1}^{r}$. Finally note that the net capital stocks available for production are $\widetilde{V}_{k, t}^{r} \equiv V_{k, t}^{r}-C_{k}^{r}\left(Q_{k, t}^{r}, V_{k, t}^{r}\right)$

On a steady-state the growth rate of each capital stock must be equal to $\gamma$, the long run growth rate. For each region $r \in R$ this gives,

$$
\frac{Q_{k}^{r}}{V_{k}^{r}}=\delta+\gamma, k \in K
$$

In addition we need to determine the steady state path of the asset prices $\Pi_{k}^{r}$ and $\Pi_{k}^{r}$. From (14) we have $\Pi_{k}^{r}=u_{k} /\left(\rho+\delta_{k}\right)$. Using this (13) and (15) gives

$$
e_{k}^{r}=\frac{u_{k}}{\rho+\delta_{k}}, k \in K
$$

\subsection{Aggregate Schooling Demand}

Households also make schooling decisions to augment their skilled labor supplies. At a point in time the labor force in each region, 1 and 2 consists of skilled workers $L S_{t}^{r}$, unskilled workers, $L U_{t}^{r}$, and those who are at school acquiring human capital, $H_{t}^{r}$, where $H_{t}^{r}=\zeta E_{t}^{r}$ and $E_{t}^{r}$ is the annual number of new graduates each of whom has attended school for $z$ years. We define a skilled worker as a worker who possesses a tertiary degree or comparable post-secondary qualifications. 
The population constraint implies $P_{t}^{r}=L S_{t}^{r}+L U_{t}^{r}+H_{t}^{r}$, and we assume that the labour force grows at a constant rate

$$
P_{t+1}^{r}=(1+b-d) P_{t}^{r}
$$

where $b_{t}$ is the birth rate and $d_{t}$ is the retirement rate. We treat $E_{t}^{r}$ as a decision variable, which effectively means that the stock of students is also chosen optimally at each point in time. The updating equation for skilled labour is then,

$$
L S_{t+1}^{r}=L S_{t}^{r}+H_{t}^{r} / \zeta-d L S_{t}^{r}
$$

Schooling is purchased in a competitive market at price $q_{e, t}^{r}$. Total spending on education services is given by $H_{t}^{r} A_{e, t}^{r} q_{e, t}^{r}$ where $A_{e, t}^{r}$ is a technical parameter that represents the level of costs per student and $q_{e, t}^{r}$ is the consumer price for education, inclusive of education subsidies. We assume further that new graduates faces costs in entering the workforce due to on-the-job-training costs, which affects their productivity. This is captured by the on-the-job training cost function $J^{r}\left(H_{t}^{r}, L S_{t}^{r}\right)$. The maximization problem that defines the households schooling investment plan is

$$
\begin{aligned}
& L_{H}^{r}=\sum_{t=0}^{\infty}\left(\frac{1}{1+\rho}\right)^{t}\left[u_{s, t}^{r} L S_{t}^{r}-u_{s, t}^{r} J^{r}\left(H_{t}^{r}, L S_{t}^{r}\right)+u_{u, t}^{r} L U_{t}^{r}-q_{e, t}^{r} A_{e, t}^{r} H_{t}^{r}\right. \\
& \left.-\Pi_{e, t}^{r}\left(L S_{t+1}^{r}-L S_{t}^{r}-E_{t}^{r}+d L S_{t}^{r}\right)\right]
\end{aligned}
$$

where

$$
J^{r}\left(H_{t}^{r}, L S_{t}^{r}\right)=\frac{\beta_{e}^{r}\left(H_{t}^{r}-b \zeta L S_{t}^{r}\right)^{2}}{2 L S_{t}^{r}}
$$

The first order condition for $E_{t}^{r}$ gives a schooling demand equation for each region,

$$
\frac{H^{r}}{L S^{r}}=\frac{\Pi_{e, t}^{r}-u_{u, t}^{r}-q_{e, t}^{r} A_{e, t}^{r}}{\beta_{e}^{r} u_{L S, t}^{r}}+b \zeta
$$

where $b$ is the steady state birth rate. 
The updating equation for $\Pi_{e, t}^{r}$ is

$$
\Pi_{e, t}^{r}=\frac{1}{1+\rho}\left(u_{L S, t+1}^{r}\left(1-J_{2}^{r}\left(H_{t+1}^{r}, L S_{t+1}^{r}\right)\right)-u_{L U, t+1}^{r}+(1-d) \Pi_{e, t+1}^{r}\right)
$$

Due to on-the-job training costs the net skilled labor available for use in production at time $t$. The net capital stocks available for production is $\tilde{L} S_{t}^{r} \equiv L S_{t}^{r}-C_{k}^{r}\left(H_{t}^{r}, L S_{t}^{r}\right)$.

On a steady state the updating equation for human capital (18) becomes

$$
\frac{H^{r}}{L S^{r}}=b \zeta
$$

On a steady state, the wage rates, $u_{u, t}^{r}, u_{u, t}^{r}$, and shadow price $\Pi_{t}^{r}$ must be growing at the growth rate of productivity, $1+\gamma$ on the balanced growth path. Let $\hat{\Pi}_{e, t}^{r} \equiv \Pi_{e, t}^{r} / A_{s, t}, u_{u, t}=\hat{u}_{u, t} / A_{u, t}$, and $\hat{u}_{s, t}=u_{s, t} / A_{s, t}$. On a steady-state we have $\hat{\Pi}_{e, t}=\hat{\Pi}_{e, t+1}, \hat{u}_{s, t}=\hat{u}_{s, t+1}, \hat{u}_{u, t}=\hat{u}_{u, t+1}$ and $J\left(H^{r}, L S^{r}\right)=0$. In the benchmark we choose units so that the ratio of efficiency units of unskilled to skilled labor is $A_{u} / A_{s} \equiv 1$.

Given these assumptions (21) becomes

$$
\hat{\Pi}_{e}^{r}=\Delta\left(\hat{u}_{L S}^{r}-\hat{u}_{L U}^{r}\right)
$$

where $\Delta \equiv(1+g) /((1+\rho)-(1-d)(1+g))$. This shows that the asset price of a unit of skilled labor is simply proportional to the skilled unskilled wage gap. Likewise on a steady state (20) becomes

$$
\hat{\Pi}_{e}^{r}=\zeta\left(\hat{u}_{L U}^{r}+q_{e}^{r}\right)
$$

which shows that the asset price of a unit of skilled labor is simply equal to the opportunity and direct costs of schooling. Combining these expressions gives the steady state relationship between the skill premium and the price of education.

$$
\hat{u}_{s}^{r}-\hat{u}_{u}^{r}=\left(q_{e}^{r}+\hat{u}_{u}^{r}\right)(\zeta / \Delta)
$$

This represents 2 additional equations that must hold in a steady-state and the two additional variables are $L S^{r}$ for $r \in R$. 


\subsection{GDP, Consumption and Government Spending}

Consumption spending is determined by a log run target debt to GDP ratio, and a consumption smoothing plan which minimizes deviations in consumption and net foreign assets from the long run target values. Here $G D P_{t}^{r}$ is defined simply as the sum of all net factor incomes, $G D P_{t}^{r}=\sum_{k \in K} w_{k} \tilde{V}_{k}^{r}+w_{L S}^{r} \tilde{L} S^{r}+w_{L U}^{r} L U^{r}+\sum_{j \in N} w_{j}^{r} V_{j}^{r}$.

Government spending is assumed to be determined by a simple policy rule that fixes aggregate spending, $G_{t}^{r}$, as a proportion of aggregate GDP.

$$
G_{t}^{r} / G D P_{t}^{r}=\omega^{r}
$$

Given income taxes, tariffs and commodity taxes, an endogenous lump sum subsidy, lump ${ }_{t}^{r}$, ensures that the government budget is balanced at each point in time.

Consumption in the steady state depends on a debt to GDP target. Net foreign assets evolve as

$$
F_{t+1}^{r}=\operatorname{surp}_{t}^{r}+(1+r) F_{t}^{r}
$$

where $\operatorname{surp}_{t}^{r}$ is the trade surplus for region $R$ at time $t$. Using the national accounting definition, substituting for $\operatorname{surp}_{t}^{r}$ and dividing by GDP at factor cost gives

$$
f_{t+1}^{r}=\left(\frac{1+\rho}{1+\gamma}\right) f_{t}^{r}+\alpha_{t}^{r}-\chi_{t}^{r}
$$

where $\alpha_{t}^{r}=1+\operatorname{tax}_{t}^{r}-\omega^{r}-$ invest $_{t}^{r}$, and tax and invest are total indirect taxes (including tariffs and subsidies), and investment spending ratios relative to GDP .

On a steady state the ratio $\alpha$ will converge to a constant. In particular, on a steady state where $f_{t+1}^{r}=f_{t}^{r}$ we have a feasibility condition

$$
\bar{f}^{r}=\frac{1+\gamma}{\gamma-\rho}\left(\alpha^{r}-\chi^{r}\right)
$$

which defines steady state consumption, $\bar{\chi}^{r}$. Thus steady state investment to GDP ratios, tax rates, government spending and debt targets determine steady state consumption, $\bar{\chi}^{r}$. If, as assumed in 
the text, the long run debt target is set to zero, then $\bar{f}=0$ so $\alpha=\chi^{r}$. This equation thus determines the level of consumption spending relative to factor income, $G D P_{t}^{r}$. Real consumption is obtained by dividing consumption spending, $\chi_{t}^{r} G D P_{t}^{r}$, by the consumption price index $e_{3}^{r}\left(q^{r}\right)$.

\subsection{Steady State Equilibrium}

Definition 1. A steady state equilibrium is a set of: consumer prices; $q_{i}^{r}$; factor prices, $w_{k}^{r}$; gross outputs; $g_{i}^{r}$, endowments $V_{k}^{r}, k \in K$ and $V_{L S}^{r}$, and consumption to GDP ratios, $\bar{\chi}^{r}$, for two regions, $R \in\{1,2\}$, which, for given values of the debt targets $\bar{f}^{r}$, a $R O W$ endowment $V_{W}$ and world prices, $q_{i}^{3}$, that satisfy:

zero profits;

$$
\phi_{i}^{r}=\sum_{j \in I} a_{j i}^{r} q_{j}^{r}-c_{i}^{r}(\mathbf{w}), i \in I, r \in R
$$

goods market clearing;

$$
\begin{gathered}
\phi_{i 1}^{1} g_{i}^{1}+\phi_{i 1}^{2} g_{i}^{2}+r_{i, 1}^{3} V_{i}^{3}=\sum_{j \in I} a_{i, j}^{1} g_{j}^{1}+a_{i, e}^{1} y_{e}^{1}+\sum_{z} d_{z, i}^{1} \quad i \in I_{T} \\
\phi_{i, 2}^{1} g_{i}^{1}+\phi_{i, 2}^{2} g_{i}^{2}+\phi_{i, 2}^{3} V_{i}^{3}=\sum_{j \in I} a_{i, j}^{2} g_{j}^{2}+a_{i, e}^{2} y_{e}^{2}+\sum_{z} d_{z, i}^{2} \quad i \in I_{T} \\
g_{i}^{r}=\sum_{j} a_{i, j}^{r} g_{j}^{r}+a_{i, e}^{r} y_{e}^{r}+\sum_{z} d_{z, i} \quad i \in I_{N}, \quad r \in R
\end{gathered}
$$

factor market clearing;

$$
\begin{gathered}
V_{k}^{r}-C\left(Q_{k}^{r}, V_{k}^{r}\right)=\sum_{i \in I} \frac{\partial c_{i}^{r}}{\partial w_{k}} g_{i}^{r} \quad r \in R, k \in K \\
L S^{r}-J\left(H^{r}, L S^{r}\right)=\sum_{i \in I} \frac{\partial c_{i}^{r}}{\partial w_{L S}^{r}} g_{i}^{r} \quad r \in R
\end{gathered}
$$




$$
\begin{gathered}
L U^{r}=\sum_{i \in I} \frac{\partial c_{i}^{r}}{\partial w_{L U}^{r}} g_{i}^{r} \quad r \in R \\
V_{k}^{r}=\sum_{i \in I} \frac{\partial c_{i}^{r}}{\partial w_{k}^{r}} g_{i}^{r} \quad k \in N, r \in R
\end{gathered}
$$

steady state capital asset pricing;

$$
\rho+\delta_{k}=\frac{u_{k}^{r}}{e_{k}^{r}}, r \in R, k \in K
$$

steady state skilled labour asset pricing;

$$
\hat{u}_{s}^{r}-\hat{u}_{u}^{r}=\left(q_{e}^{r}+\hat{u}_{u}^{r}\right)(\zeta / \Delta), r \in R
$$

and steady state consumption feasibility;

$$
\alpha^{r}=\chi^{r}, r \in R
$$

A steady state equilibrium thus consists of 68 equations and 68 unknowns consisting of: 22 zero profit conditions; 22 commodity market clearing conditions; 14 factor market clearing conditions; 2 human capital asset price equations; 6 steady state capital asset price conditions, and; 2 debt target feasibility conditions that solve; solving $2 \times 11$ commodity prices; $q_{i}^{r} ; 2 \times 7$ factor prices; $w_{k}^{r}$, and; $2 \times 11$ gross outputs, $g_{i}^{r}, 2$ skilled labor endowments, $L S^{r} ; 2 \times 3$ regional physical capital stocks, $V_{k, t}^{r}, k \in K$, and; 2 consumption spending to GDP in each region, $\bar{\chi}^{r}$. Paramter values are given in the following Table. The solution is obtained using numerical methods described in Press et al (1990). 
Parameter Values (all regions)

\begin{tabular}{|cc|}
\hline & Base Values \\
\hline CET Revenue Parameter, $\eta$ & \\
Agriculture & \\
Minerals & 3.90 \\
Low-Tech Manufacture & 2.90 \\
Intermediate Manufacture & 2.90 \\
Durables & 2.90 \\
Traded Services & 2.90 \\
CES Expenditure Parameter all sectors & 0.70 \\
CES Unit Cost Functions & -0.80 \\
Upper Nest Substitution Elasticity, $\sigma$ & \\
Lower Nest Substitution Elasticity, $v$ & 1.67 \\
Machinery and Equipment & 0.67 \\
Structures & \\
Residential Housing & 10.0 \\
Investment Adjustment Cost Function constants, $\beta$ & 90.0 \\
Training Cost Function constant, $\beta_{e}$ & 90.0 \\
\end{tabular}




\section{Variable and Model Definitions}

\begin{tabular}{|c|c|}
\hline \multicolumn{2}{|l|}{ Sets } \\
\hline Regions & $\bar{R} \in\{1,2,3\}$ \\
\hline Non ROW regions & $R \in\{1,2\}, R \subset \bar{R}$ \\
\hline Sectors $I$ & $I=\{1, \ldots, 11\}$ \\
\hline Traded Sectors, $I_{T}$ & $I_{T}=\{1, \ldots, 6\}, I_{T} \subset I$ \\
\hline Non Traded Sectors, $I_{N}$ & $I_{N}=\{7, \ldots, 11\}, I_{N} \subset I$ \\
\hline Spending types, $Z$ & $Z=\{1, \ldots, 5\}$ \\
\hline Factors, $\bar{K}$ & $\bar{K}=\{1, \ldots, 7\}$ \\
\hline $\begin{array}{l}\text { Physical Capital Factors, } \\
K\end{array}$ & $K=\{1, \ldots, 3\}, K \subset \bar{K}$ \\
\hline \multicolumn{2}{|l|}{ Regions } \\
\hline 1 & USA \\
\hline 2 & China or India \\
\hline 3 & $R O W$ \\
\hline \multicolumn{2}{|l|}{ Spending Types } \\
\hline 1 & Machinery and Equipment Spending \\
\hline 2 & Structures Investment \\
\hline 3 & Residential Capital Investment \\
\hline 4 & Consumption \\
\hline 5 & Government \\
\hline \multicolumn{2}{|l|}{ Factors of Production } \\
\hline 1 & Machinery and Equipment \\
\hline 2 & Structures \\
\hline 3 & Residential Capital \\
\hline 4 & Skilled labor \\
\hline 5 & Unskilled labor \\
\hline 6 & Land \\
\hline 7 & Resources \\
\hline \multicolumn{2}{|l|}{ Sectors } \\
\hline 1 & Agriculture \\
\hline 2 & Minerals \\
\hline 3 & Low-tech \\
\hline 4 & Intermediate Manufacturing \\
\hline 5 & Durables \\
\hline 6 & Traded Services \\
\hline 7 & Construction \\
\hline 8 & Non-Traded Services \\
\hline 9 & Public \\
\hline 10 & Housing \\
\hline 11 & Education \\
\hline
\end{tabular}




\begin{tabular}{|c|c|}
\hline \multicolumn{2}{|c|}{ Non Price Variables } \\
\hline$g_{i}^{r}$ & Real gross output flow by sector $i, i \in I$ \\
\hline$V_{W}$ & Endowment for ROW region \\
\hline$V_{k}^{r}$ & Aggregate stock of reproducible input, $k, k \in K$ \\
\hline$V_{k, i}^{r}$ & Stock of reproducible inputs in sector $i, k \in K, i \in I$ \\
\hline$L S^{r}$ & Aggregate stock of skilled labor \\
\hline$L U^{r}$ & Stock of unskilled labor \\
\hline$M_{i}^{r}$ & Intermediate input aggregator for each sector $i$ \\
\hline$a_{i, j}^{r}$ & Intermediate use coefficient for good $j$ by sector $I, i \in I, j \in I$ \\
\hline$Y_{i, j}^{r}$ & Quantity of intermediate use for each good $j$ used as an input in sector $i$ \\
\hline$x_{i}^{\bar{R}, j}$ & Output of traded good in sector $i$ of region with destination $j \in\{1,2,3\}$ \\
\hline$Q_{z}^{r}$ & Real quantity index for each spending type, $z \in Z$ \\
\hline$G^{r}$ & Government spending for each region \\
\hline$G D P^{r}$ & GDP at factor cost \\
\hline$\omega^{r}$ & Ratio of government spending to GDP \\
\hline$\chi^{r}$ & Ratio of consumption spending to GDP \\
\hline$Q_{k}^{r}$ & Investment demand for asset type $k$ for each region $R, k \in\{M, S, D\}$ \\
\hline$H^{r}$ & Stock students for each region \\
\hline$E^{r}$ & Annual number of new graduates for each region \\
\hline$A_{e}^{r}$ & Technical parameter for level of costs per student for each Region \\
\hline$A_{k}^{r}$ & Technical parameter for level of effective factor supply \\
\hline$f_{t}^{r}$ & Current level of net foreign assets to GDP ratio at time $t$ \\
\hline $\bar{f}_{t}^{r}$ & Target level of net foreign assets to GDP ratio \\
\hline$v_{i}^{r}$ & Value added in $R \in\{1,2\}$ \\
\hline$\phi_{i}^{r}$ & Revenue in region $r \in \bar{R}$ \\
\hline$J^{r}$ & On-the-job training cost function \\
\hline$C_{k}^{r}$ & Capital installation costs function \\
\hline surp $^{r}$ & Ratio of consumption spending to GDP \\
\hline lump ${ }^{r}$ & Lump sum tax to balance government budget. \\
\hline
\end{tabular}




\begin{tabular}{|c|c|}
\hline \multicolumn{2}{|c|}{ Prices } \\
\hline$\Pi_{L S}^{r}$ & Shadow price of a unit of skilled labor. \\
\hline$\Pi_{k}^{r}$ & Shadow prices of a unit of capital of asset type $k$. \\
\hline$\Pi_{e}^{r}$ & Shadow prices of a unit of skilled labor. \\
\hline$p_{k}^{r}$ & Producer prices of a unit of investment in each asset type $k \in\{M, S, D\}$ \\
\hline$u_{k}^{r}$ & After tax rental rates on asset type $k$ for each region \\
\hline$p_{i}^{\bar{R}, j}$ & Producer prices in each region of sector $i$ in region $\bar{R} \in\{1,2,3\}$ sold in $j \in\{1,2,3\}$. \\
\hline$q^{r}$ & Vector of consumer prices in each region \\
\hline$q_{i}^{r}$ & Consumer prices in each region for sector $i$. \\
\hline$e_{z}^{r}$ & Unit expenditure for each spending type. \\
\hline$p_{e}^{r}$ & Producer price of education inclusive of education subsidies \\
\hline$q_{e}^{r}$ & Consumer price of education inclusive of education subsidies \\
\hline$d_{z, i}^{r}$ & Demand for sector $i$ from spending type $z$. \\
\hline$u_{s}^{r}$ & After tax skilled wages for each region $R$. \\
\hline$u_{u}^{r}$ & After tax unskilled wages for each region $R$. \\
\hline$w_{k}$ & Factor prices. \\
\hline$\hat{w}_{k}$ & Factor prices per efficiency unit. \\
\hline \multicolumn{2}{|c|}{ Parameters } \\
\hline$\delta_{k}$ & Depreciation rates on asset type $k$. \\
\hline$\Gamma_{k}^{r}$ & Factor tax \\
\hline$\tau^{j \bar{R}}$ & Tariff rate rates by region $j$ on each region $\bar{R}$ 's exports. \\
\hline$\sigma$ & Elasticity of substitution parameter in upper nest of cost function \\
\hline$v$ & Elasticity of substitution parameter in lower nest of cost function \\
\hline$\beta_{k}^{r}$ & Parameter of the adjustment cost function. \\
\hline$\beta_{e}^{r}$ & Parameter for the adjustment cost function for human capital \\
\hline$\gamma$ & Steady state growth rate of the economy. \\
\hline$\alpha$ & Parameter for the growth rate of consumption per worker. \\
\hline$\zeta$ & Number of years in which new graduates have attended school \\
\hline$n^{r}$ & labor Force growth rate. \\
\hline$\lambda^{r}$ & Debt target parameter in the inter-temporal consumption function \\
\hline
\end{tabular}




\begin{tabular}{|c|c|c|}
\hline \multicolumn{3}{|c|}{$\begin{array}{c}\text { ECONOMICS DISCUSSION PAPERS } \\
2009\end{array}$} \\
\hline $\begin{array}{l}\text { DP } \\
\text { NUMBER }\end{array}$ & AUTHORS & TITLE \\
\hline 09.01 & Le, A.T. & $\begin{array}{l}\text { ENTRY INTO UNIVERSITY: ARE THE CHILDREN OF } \\
\text { IMMIGRANTS DISADVANTAGED? }\end{array}$ \\
\hline 09.02 & $\mathrm{Wu}, \mathrm{Y}$. & CHINA'S CAPITAL STOCK SERIES BY REGION AND SECTOR \\
\hline 09.03 & Chen, M.H. & $\begin{array}{l}\text { UNDERSTANDING WORLD COMMODITY PRICES RETURNS, } \\
\text { VOLATILITY AND DIVERSIFACATION }\end{array}$ \\
\hline 09.04 & Velagic, R. & UWA DISCUSSION PAPERS IN ECONOMICS: THE FIRST 650 \\
\hline 09.05 & McLure, M. & $\begin{array}{l}\text { ROYALTIES FOR REGIONS: ACCOUNTABILITY AND } \\
\text { SUSTAINABILITY }\end{array}$ \\
\hline 09.06 & Chen, A. and Groenewold, N. & $\begin{array}{l}\text { REDUCING REGIONAL DISPARITIES IN CHINA: AN } \\
\text { EVALUATION OF ALTERNATIVE POLICIES }\end{array}$ \\
\hline 09.07 & Groenewold, N. and Hagger, A. & $\begin{array}{l}\text { THE REGIONAL ECONOMIC EFFECTS OF IMMIGRATION: } \\
\text { SIMULATION RESULTS FROM A SMALL CGE MODEL. }\end{array}$ \\
\hline 09.08 & Clements, K. and Chen, D. & AFFLUENCE AND FOOD: SIMPLE WAY TO INFER INCOMES \\
\hline 09.09 & Clements, K. and Maesepp, M. & A SELF-REFLECTIVE INVERSE DEMAND SYSTEM \\
\hline 09.10 & Jones, C. & $\begin{array}{l}\text { MEASURING WESTERN AUSTRALIAN HOUSE PRICES: } \\
\text { METHODS AND IMPLICATIONS }\end{array}$ \\
\hline 09.11 & Siddique, M.A.B. & $\begin{array}{l}\text { WESTERN AUSTRALIA-JAPAN MINING CO-OPERATION: AN } \\
\text { HISTORICAL OVERVIEW }\end{array}$ \\
\hline 09.12 & Weber, E.J. & $\begin{array}{l}\text { PRE-INDUSTRIAL BIMETALLISM: THE INDEX COIN } \\
\text { HYPTHESIS }\end{array}$ \\
\hline 09.13 & McLure, M. & $\begin{array}{l}\text { PARETO AND PIGOU ON OPHELIMITY, UTILITY AND } \\
\text { WELFARE: IMPLICATIONS FOR PUBLIC FINANCE }\end{array}$ \\
\hline 09.14 & Weber, E.J. & $\begin{array}{l}\text { WILFRED EDWARD GRAHAM SALTER: THE MERITS OF A } \\
\text { CLASSICAL ECONOMIC EDUCATION }\end{array}$ \\
\hline 09.15 & Tyers, R. and Huang, L. & $\begin{array}{l}\text { COMBATING CHINA'S EXPORT CONTRACTION: FISCAL } \\
\text { EXPANSION OR ACCELERATED INDUSTRIAL REFORM }\end{array}$ \\
\hline 09.16 & $\begin{array}{l}\text { Zweifel, P., Plaff, D. and } \\
\text { Kühn, J. }\end{array}$ & $\begin{array}{l}\text { IS REGULATING THE SOLVENCY OF BANKS COUNTER- } \\
\text { PRODUCTIVE? }\end{array}$ \\
\hline 09.17 & Clements, $\mathrm{K}$. & THE PHD CONFERENCE REACHES ADULTHOOD \\
\hline 09.18 & McLure, M. & $\begin{array}{l}\text { THIRTY YEARS OF ECONOMICS: UWA AND THE WA } \\
\text { BRANCH OF THE ECONOMIC SOCIETY FROM } 1963 \text { TO } 1992\end{array}$ \\
\hline 09.19 & Harris, R.G. and Robertson, P. & $\begin{array}{l}\text { TRADE, WAGES AND SKILL ACCUMULATION IN THE } \\
\text { EMERGING GIANTS }\end{array}$ \\
\hline 09.20 & $\begin{array}{l}\text { Peng, J., Cui, J., Qin, F. and } \\
\text { Groenewold, N. }\end{array}$ & STOCK PRICES AND THE MACRO ECONOMY IN CHINA \\
\hline 09.21 & Chen, A. and Groenewold, N. & $\begin{array}{l}\text { REGIONAL EQUALITY AND NATIONAL DEVELOPMENT IN } \\
\text { CHINA: IS THERE A TRADE-OFF? }\end{array}$ \\
\hline
\end{tabular}




\begin{tabular}{|c|c|c|}
\hline \multicolumn{3}{|c|}{$\begin{array}{c}\text { ECONOMICS DISCUSSION PAPERS } \\
2010\end{array}$} \\
\hline $\begin{array}{l}\text { DP } \\
\text { NUMBER }\end{array}$ & AUTHORS & TITLE \\
\hline 10.01 & Hendry, D.F. & $\begin{array}{l}\text { RESEARCH AND THE ACADEMIC: A TALE OF } \\
\text { TWO CULTURES }\end{array}$ \\
\hline 10.02 & McLure, M., Turkington, D. and Weber, E.J. & A CONVERSATION WITH ARNOLD ZELLNER \\
\hline 10.03 & $\begin{array}{l}\text { Butler, D.J., Burbank, V.K. and } \\
\text { Chisholm, J.S. }\end{array}$ & $\begin{array}{l}\text { THE FRAMES BEHIND THE GAMES: PLAYER'S } \\
\text { PERCEPTIONS OF PRISONER'S DILEMMA, } \\
\text { CHICKEN, DICTATOR, AND ULTIMATUM GAMES }\end{array}$ \\
\hline 10.04 & Harris, R.G., Robertson, P.E. and Xu, J.Y. & $\begin{array}{l}\text { THE INTERNATIONAL EFFECTS OF CHINA'S } \\
\text { GROWTH, TRADE AND EDUCATION BOOMS }\end{array}$ \\
\hline 10.05 & Clements, K.W., Mongey, S. and Si, J. & $\begin{array}{l}\text { THE DYNAMICS OF NEW RESOURCE PROJECTS } \\
\text { A PROGRESS REPORT }\end{array}$ \\
\hline
\end{tabular}

